\title{
Sedimentary Records of Paleogene (Eocene to Lowermost Miocene) Deformations near the Contact between the Carpathian Thrust Belt and Moesia
}

\author{
T. Rabagia ${ }^{1 *}$, R.-D. Roban ${ }^{2}$ and M. Tarapoanca ${ }^{1}$ \\ 1 Danubian Energy Consulting, 42-44 Vasile Lascar, 5th floor, 11 th suite, Bucharest 2 - Romania \\ 2 Bucharest University, Faculty of Geology and Geophysics, Traian Vuia 6, Bucharest 2 - Romania \\ e-mail: trabagia@danubianenergy.com - reludumitru.roban@g.unibuc.ro - mtarapoanca@danubianenergy.com \\ * Corresponding author
}

Résumé - Enregistrements sédimentaires des déformations d'âge Éocène à Miocène inférieur dans la zone de contact du front des Carpathes et de la plateforme moésienne - Les modèles cinématiques proposés pour l'évolution des Carpathes roumaines au Tertiaire expliquent la forme arquée de cette chaîne de montagnes par le mouvement de la plaque supérieure (bloc de Tisza-Dacia) autour de la marge occidentale, puis le long de la marge septentrionale de la Moésie, cette dernière représentant l'avant-pays de la chaîne et le substratum de la partie méridionale du bassin flexural. Les principaux événements tectoniques sont survenus pendant l'Eocène quand l'ensemble chevauchant (formé vers la fin du Crétacé et représentant les Carpathes méridionales actuelles) a subi une extension. Cet épisode a été suivi d'une translation décrochante dextre accompagnée de l'ouverture de la Dépression Gétique en bassin de pull-apart sur la marge septentrionale de la Moésie (en termes géographiques, le piémont des Carpathes méridionales). La deuxième déformation s'est déroulée pendant l'intervalle OligocèneMiocène inférieur. Même si, à partir du Miocène inférieur, l'avancement progressif du bloc Tisza-Dacia vers l'est a induit des structures assez bien définies dans la zone frontale du prisme tectonique (Carpathes orientales) et sur sa bordure latérale (Dépression Gétique), la tectonique de l'Eocène-Miocène inférieur n’a apparemment laissé aucun signe de déformation sur la ceinture déformée externe. Nous avons recherché des marqueurs tectoniques de cet intervalle de temps en construisant et intégrant des colonnes sédimentaires détaillées dans la zone du contact entre les Carpathes externes et la Moésie. Deux catégories principales d'associations de faciès sédimentaires ont été définies en termes d'énergie de dépôt: des associations proximales progradantes de haute énergie représentées par des unités sédimentaires plus grossières et associations distales aggradantes d'énergie variable. Une origine tectonique (syn-cinématique) des unités de haute énergie est envisagée grâce à l'érosion significative observée à leur base, la provenance des grains détritiques et les pendages des couches indiquant en général des discordances angulaires. Une conclusion importante est que la corrélation régionale des formations d'âge Éocène-Miocène basal indique une migration progressive spatiale et temporale des unités sédimentaires de haute énergie qui deviennent plus jeunes vers l'est, en accord avec la direction du transport tectonique de la plaque supérieure du système carpathique.

Abstract - Sedimentary Records of Paleogene (Eocene to Lowermost Miocene) Deformations near the Contact between the Carpathian Thrust Belt and Moesia - The kinematic models proposed for the Tertiary evolution of the Romanian Carpathians explain its arcuate shape by the progressive 
displacement of the upper plate (Tisza-Dacia block) around the western margin and then along the northern margin of Moesia, the latter representing the stable foreland autochthon. The main tectonic events took place in the Eocene when a former nappe pile, formed by the end of the Cretaceous and representing the actual Southern Carpathians, underwent extension. This episode was followed by dextral wrenching that was accompanied by the opening of the Getic Depression as a pull-apart basin along the northern Moesian margin, at the current location of the Southern Carpathian foothills. This deformation operated from Oligocene to Lower Miocene times. Although from the Lower Miocene onwards the progressive eastwards motion of the Tisza-Dacia block accounted for well-defined accommodating structures in both the frontal (Eastern Carpathians) and lateral (Getic Depression) sides of the accretionary wedge, the Eocene to Lower Miocene tectonics left apparently no imprint upon the outer thin-skinned belt.

We have looked for the sedimentary records of these tectonic events by building and integrating several detailed sedimentary logs near the contact between the Outer Carpathians and Moesia. Two main facies associations were defined in terms of basin energy, i.e. proximal high-energy prograding associations, represented by coarser sedimentary units and distal variable-energy aggrading associations. Based on the wide incision observed at the base of the high-energy units and on the clast provenance, we assume a tectonic origin for the vertical changes observed in the dipping attitude of the beds, which account for angular unconformities. Importantly, the regional correlation of the Eocene-Lowermost Miocene formations points to a progressive migration in time and space of the high-energy sedimentary units, which get younger eastwards, consistent with the direction of the tectonic transport of the Carpathian allochthon.

\section{INTRODUCTION}

The overall structural architecture of the South eastern Carpathian thin-skinned belt results from a progressive shortening which began as early as the Mid-Cretaceous, due to the closure of the former Upper Jurassic-Cretaceous CeahlauSeverin ocean (Schmid et al., 2008). The innermost nappe, namely the Ceahlau nappe, was deformed and accreted to the tectonic wedge during the Cretaceous, forming the External Dacides, sensu Sandulescu (1984). In contrast, the Outer Carpathian nappes, comprising the Curbicortical Flysch, Audia, Tarcau, Marginal Fold and Subcarpathian nappes, were stacked later during Miocene episodes of shortening, resulting in the formation of the Moldavides (Sandulescu, 1984; Fig. 1).

The post-Cretaceous evolution of the Carpathian system is dominated by an eastward migration of the arc, accommodated by large-scale transcurrent movements along its southern segment (Southern Carpathians) and synchronous compression in its frontal part (Eastern Carpathians). This process took place during the 90 degrees clockwise rotation of the Tisza-Dacia unit around the Moesian Platform (e.g., Csontos et al., 1992 and references therein).

Despite the fact that the models predict a synchronous strike-slip motion in the south and compression in the east (e.g. Schmid et al., 2008), the shortening recorded in the Eastern Carpathians was mainly acquired during the MiddleLate Miocene (Sandulescu, 1984, 1988), in contrast to the Paleogene-Early Miocene age of dextral translations along curved dextral faults in the Southern Carpathians-Balkans (Fig. 1, Fugenschuh and Schmid, 2005; Tarapoanca et al., 2007). Such discrepancy in the ages is due to the fact that
Eocene-Early Miocene contractional deformation has been mostly overlooked.

In order to understand and address the issue of this "time gap" we focus on the Eocene-Lower Miocene sedimentary records from outcrops located at the transition zone between the frontal part of the Tisza-Dacia blocks (Eastern Carpathian thrust system) and the lateral border of the aforementioned blocks (Southern Carpathians-Getic Depression). The area covers two different tectonic units (Fig. 1) controlling the development, at least from the Eocene onwards, of two coeval and linked sedimentary basins: the Getic Depression in the south and the Moldavides in the east (e.g. Sandulescu, 1988).

In the Getic Depression, sedimentation started in the Uppermost Cretaceous being triggered by the flexural downbending of the Moesian foreland lithosphere resulting from the Cretaceous nappe emplacement and tectonic loading operating in the Southern Carpathians (Berza et al., 1983; Iancu et al., 2005). During Latest Campanian-Paleogene times, the flexural space created at the contact between the Southern Carpathians and the Moesian Platform by the Cretaceous episode of crustal thickening was filled by shallow-water sediments (e.g., Jipa, 1980, 1984). The Miocene basin was characterized by a pull-apart-type evolution (Rabagia and Matenco, 1999). It contains more than 3-kmthick, mainly siliciclastic sediments which were deformed during Late Miocene inversion stages (Rabagia et al., 2011), creating the Subcarpathian nappe (Fig. 1). In the Eastern Carpathians, coeval Subcarpathian units were thrust over the undeformed foreland (Sandulescu, 1984, 1988; Matenco and Bertotti, 2000). 


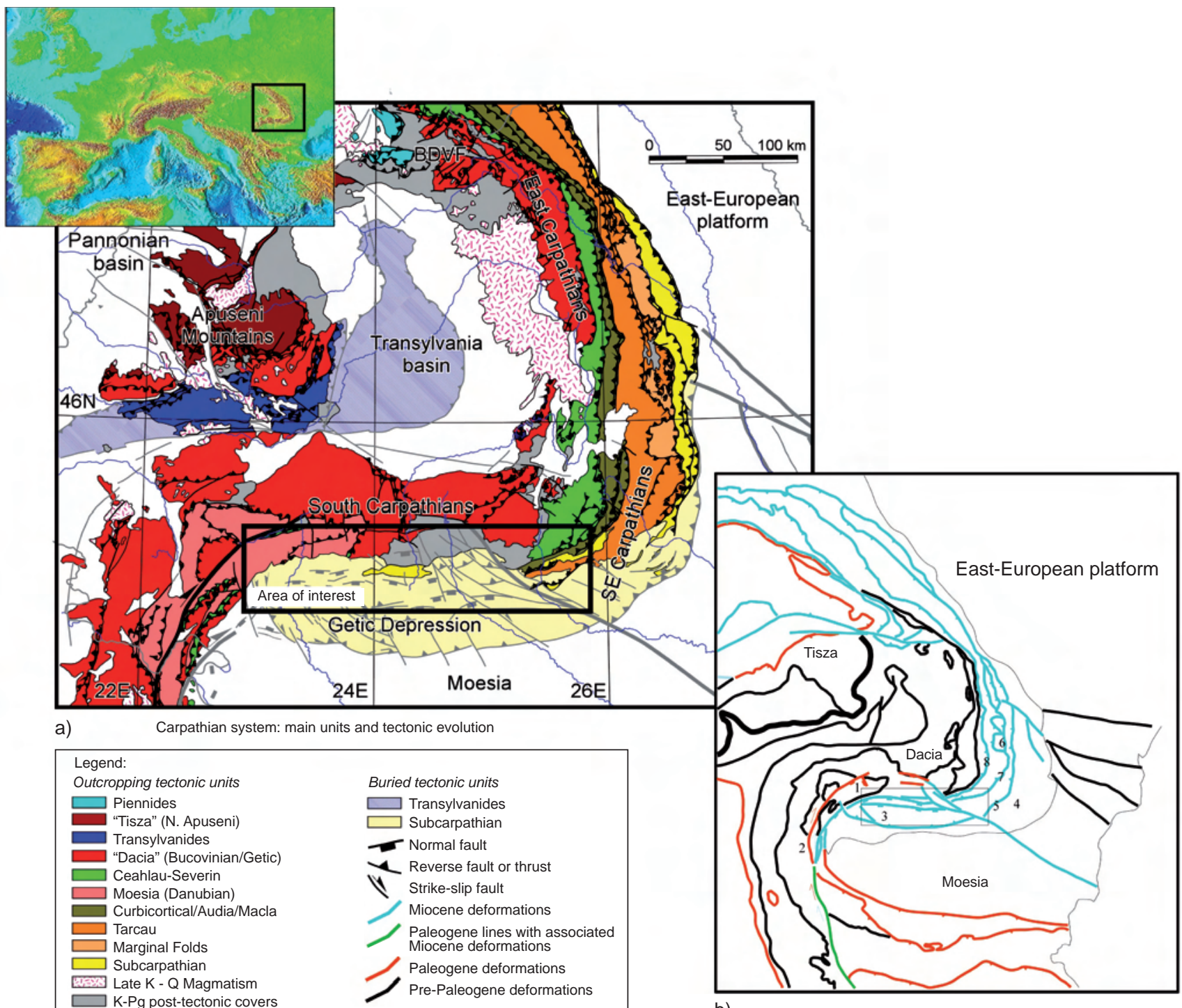

b)

Figure 1

a) Tectonic map of the Romanian Carpathians updated from Sandulescu (1984) with data from Rabagia and Matenco (1999), Tarapoanca et al. (2007), Schmid et al. (2008), and Rabagia et al. (2011). The location of the map is depicted in the upper left European topographic inset. b) Paleogene-Miocene evolutionary sketch depicting age of deformation along major faults, modified after Schmidt et al. (2008); 1: Cerna strike-slip fault; 2: Timok strike-slip fault; 3: Getic Depression strike-slip system; 4: Carpathian foredeep; 5: Subcarpathian thrust; 6: Marginal Fold thrust; 7: Tarcau thrust; 8: Audia thrust.

The Moldavides units (Fig. 1) comprise deformed sedimentary successions made up especially of Cretaceous to Oligocene flysch and Miocene molasses (e.g. Sandulescu, 1984, 1988). A general forelandwards-directed nappe stacking accounts for the present-day structural architecture with only minor out-of-sequence thrusting (Matenco and Bertotti, 2000). The bulk of the Eocene to Lowermost Miocene sequences preserved in the highly shortened Eastern Carpathian belt (around $180 \mathrm{~km}$ of shortening during the
Neogene only, cf. Roure et al., 1993) were interpreted as deep water, dominantly clastic turbidites organized in various assemblages that interfinger with fine basinal sediments shed into a foredeep basin with euxinic conditions prevailing during the Oligocene (Sandulescu, 1984; Gigliuto et al., 2004; Sylvester and Lowe, 2004; Miclaus et al., 2009). Facies and provenance changes were interpreted as a result of the interplay between longitudinal and transversal sediment transport (Jipa, 1966; Contescu, 1974), although other authors observed 
that in some cases, important changes in basin topography are required to explain similar sedimentological features (Atanasiu, 1958; Puligsi et al., 2006; Belayouni et al., 2009). However, the Oligocene facies correlation and spatial distribution within the Southern and the Eastern Carpathians were and still are a subject of debate, impacting on the accuracy of local structural models describing the regional evolution of the belt. The main causes for lacking consensus relate to the inherent complex architecture of such depositional systems, severe thrusting, the lack of regionally correlable markers and scarcity of index fossil groups. Consequently, various correlation schemes have been proposed by many scholars.

Although it is difficult to understand and integrate all the local delineated formations, we attempted a regional correlation scheme (Fig. 2) needed for further sedimentological and field work based on the opinions of Stefanescu et al. (1993), Stefanescu (1995), Roban and Melinte (2005), and Melinte and Brustur (2008). A detailed description of the Eocene to Miocene formations covered in Figure 2 is given in the next sections. Actually, the key problem for describing the Eocene-Lower Miocene stratigraphy of the Carpathians relates to the poor exposure of the stratigraphic contacts and lateral/vertical correlations among the various litho-facies. Despite the fact that many authors (e.g. Bucur, 1966;
Stefanescu, 1995) reported erosional features and important vertical and lateral changes in the basin sedimentary energy as a measure of coarse sediment occurrence - and source areas (e.g. Roban and Melinte, 2005; Puglisi et al., 2006), these features were considered as local exceptions, the general rules being continuity and contemporaneousness.

Our analysis begins with sedimentological logs built along several long exposures, which are subsequently integrated into a regional model of sedimentary patterns occurring in time and space. Correlating the high-energy, coarse facies that follow the erosional unconformities provide finally valuable insights into the tectonic imprint on the sedimentation during the Eocene-Lowermost Miocene.

\section{OVERVIEW OF THE PALEOGENE PETROLEUM SYSTEMS}

Although our work does not focus on petroleum issues that would relate the new correlation scheme of the EoceneLowermost Miocene sedimentary sequences to hydrocarbon field distribution (either on a regional or local scale) or on the impact that these new findings could have on assessing certain particular structural style(s) of traps, a review of the petroleum potential is given hereinafter as the study area

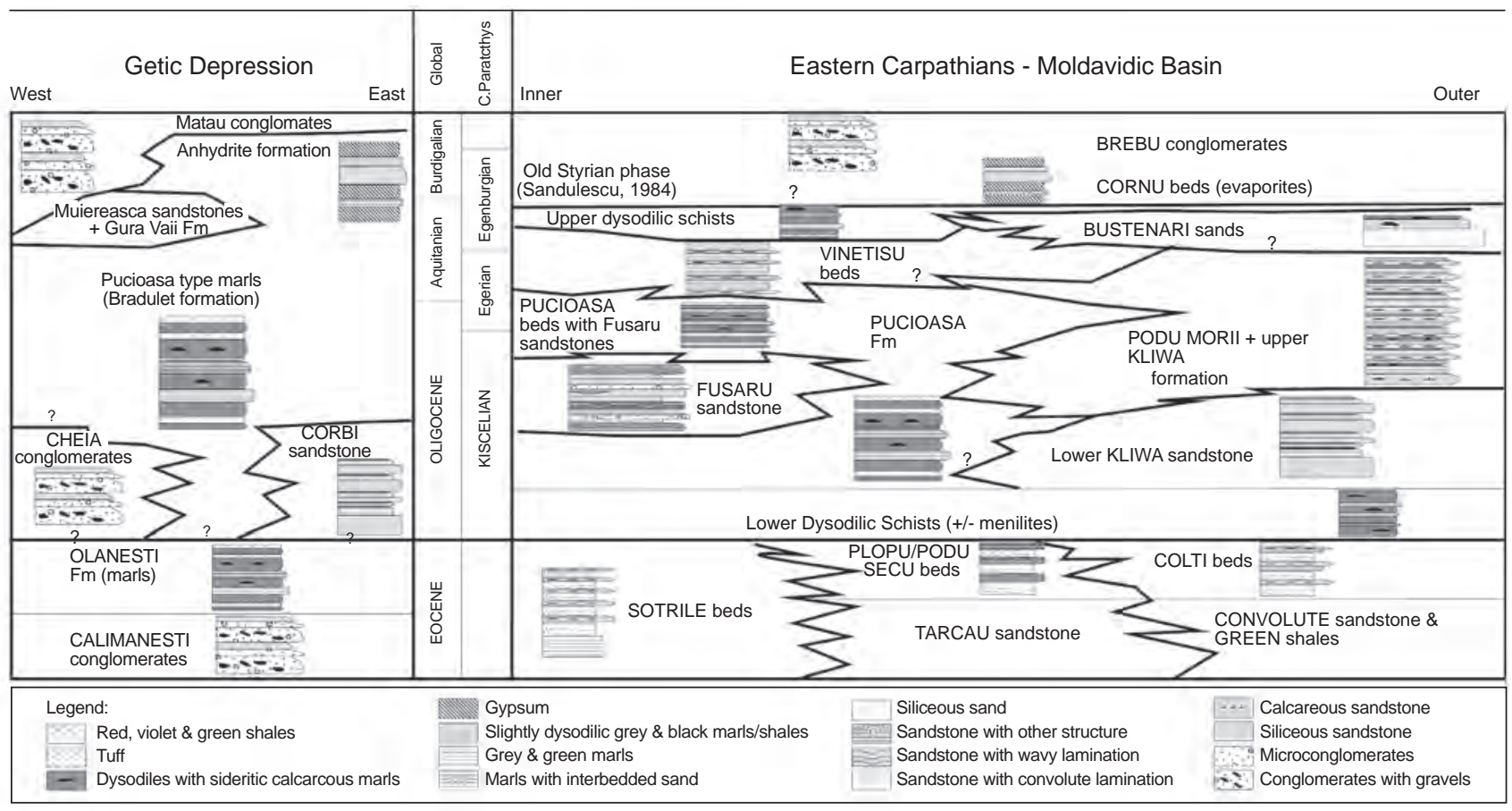

Figure 2

General correlation of the Eocene-Lower Miocene formations within the Getic Depression and the Southern Moldavidic Basin (Southeastern Carpathians). Sedimentary logs depict the dominant facies of each formation. References and descriptions in text. Paleogene time scale after Melinte and Brustur (2008). Note the diachronism of many units. 
(Fig. 1) encompasses part of the oldest and still a major petroleum province, which is defined as the Carpathian Paleogene petroleum system by Popescu (1995) or Dysodile Schist - Tertiary total petroleum system (Outer East Carpathians together with the Getic Depression) by Pawlewicz (2007). In a recent update given by the main operating company (OMV-Petrom), the discovered reserves within the Romanian Paleogene flysch and Neogene molasse units of the Eastern Carpathians including the Bend zone amount to $410.8 \mathrm{MM}$ tons of oil and $52.7 \mathrm{Bcm}$ gas, whereas in the Getic Depression they amount to $126 \mathrm{MM}$ tons of oil and $127 \mathrm{Bcm}$ gas (Gilbert, 2007). The most prolific source for hydrocarbons all along the Outer Carpathians is represented by the Oligocene to Lowermost Miocene black shales/marls including the organic matter-bearing siliceous rocks (menilites) of the Lower and Upper Dysodilic Schists, the dysodiles interbedded within the Kliwa sandstones and the Pucioasa Formation (Fig. 2). According to Popescu (1995) and Stefanescu et al. (2006), the kerogen is type II, partly mixed II-III, while the TOC ranges differ from one reference to another $(0.35 \%-7.65 \%$ after Popescu, 1995; $0.7 \%$ - >10\% after Stefanescu et al., 2006; 3.7\% - >29\% after Pawlewicz, 2007). Nevertheless, these units are generally ranked as good-to-excellent hydrocarbon sources although the outcrop samples often indicate that they are thermally immature (e.g. Belayouni et al., 2009). Although before World War II some other stratigraphic units were also assumed to account for $\mathrm{HC}$ generation, these fine-grain Oligocene sequences were historically recognized as the main source of HC in the Outer Carpathians, particularly in the Bend zone (Hlauschek, 1950; Small, 1959).

Coarser grain Eocene to Lowermost Miocene formations constitute the main reservoirs within many hydrocarbon fields, although $\mathrm{HC}$ have been found in a much larger stratigraphic interval, comprising the Upper Cretaceous to Latest Miocene-Pliocene deposits (the latter had been firstly discovered and produced in the Carpathian Bend zone; Hlauschek, 1950; Small, 1959). The Fusaru sandstones and, to a larger extent, the Lower and Upper Kliwa sandstones (Fig. 2) are in many instances high-quality reservoirs, often sealed by the same shales/marls previously mentioned as source intervals (Stefanescu et al., 2006).

All hydrocarbon fields in the study area have essentially structural traps (e.g. Small, 1959; Stefanescu et al., 2006 and references therein) varying from simpler geometries such as moderately faulted anticlines to highly complex assemblages of duplexes or disharmonic diapirs interfering with the thrust systems. Most of the major fields in the Carpathian Bend zone were discovered before World War II, at the dawn of $\mathrm{E}$ \& $\mathrm{P}$ activities in Romania (in "Ploiesti district", as it was called by the companies operating in the first half of the 20th century, see for instance Small, 1959). The initial production was established from the Latest Miocene (Meotian) and Early Pliocene sands within compressional traps of moderate complexity (at least from the present-day perspective; see relevant examples of major findings in Small, 1959). Deeper reservoirs were added later to the reserve portfolio for these fields, as well as other new structures; however, the level of structural complexity was found to dramatically increase at deeper levels in the Eocene to Lowermost Miocene formations. Imagining in a viable manner the buried structural architecture depends crucially on the accuracy of the correlation between the above-mentioned sedimentary sequences, which we will be trying to elucidate in the following sections.

A main issue of the so-called Paleogene petroleum system (Popescu, 1995) remains the degree of understanding of the maturity distribution within the potential source rocks (dysodile units). Due to the complex Middle-Upper Miocene structural evolution, the Oligocene units reach the oil window at depths exceeding $4500 \mathrm{~m}$ (Stefanescu et al., 2006). No attempt has been made yet to test the deeply buried duplexes and current structural models hardly explain the shallower $\mathrm{HC}$ accumulations discovered in the inner Tarcau nappe.

\section{METHODS}

This paper is based on data obtained by cartographic and sedimentological means from the Eocene-Lower Miocene sedimentary units cropping out between the Valsan valley (Southern Carpathian foothills - inner part of the Getic Depression) and the Teleajen valley (Eastern Carpathian bend zone, Fig. 1). Two main criteria were used to delineate significant correlable units: the dipping attitude of the beds especially in the surface anticlines - and basin sedimentary energy changes as recorded by different facies associations. In some areas, a relatively good well data coverage was available (Fig. 3) due to the importance of the Oligocene sediments for the petroleum systems of the Outer Carpathians. Without aiming at detailed sedimentological analysis and results, but trying to understand on a wider scale the sedimentary system energy changes recorded by the Eocene-Lower Miocene sediments, several facies units and associations (Fig. 4) were defined and then correlated across the study area:

\subsection{F 1 - Prograding Units, High Energy}

This facies association comprises a wide variety of dominantly coarse sediments, controlled by both mass (debris-flow) and channeling (stream-flow) transport building altogether largerscale prograding bodies. Although the small-scale facies are characterized by limited individual lateral correlativity and a high vertical frequency of erosional surfaces, well-individualized sedimentary units are characterized by high-energy transport with associated current laminations, and locally imbricated channel-fill sets, clasts in conglomerates and large-scale progradation features. This unit was further divided into three main facies associations. 


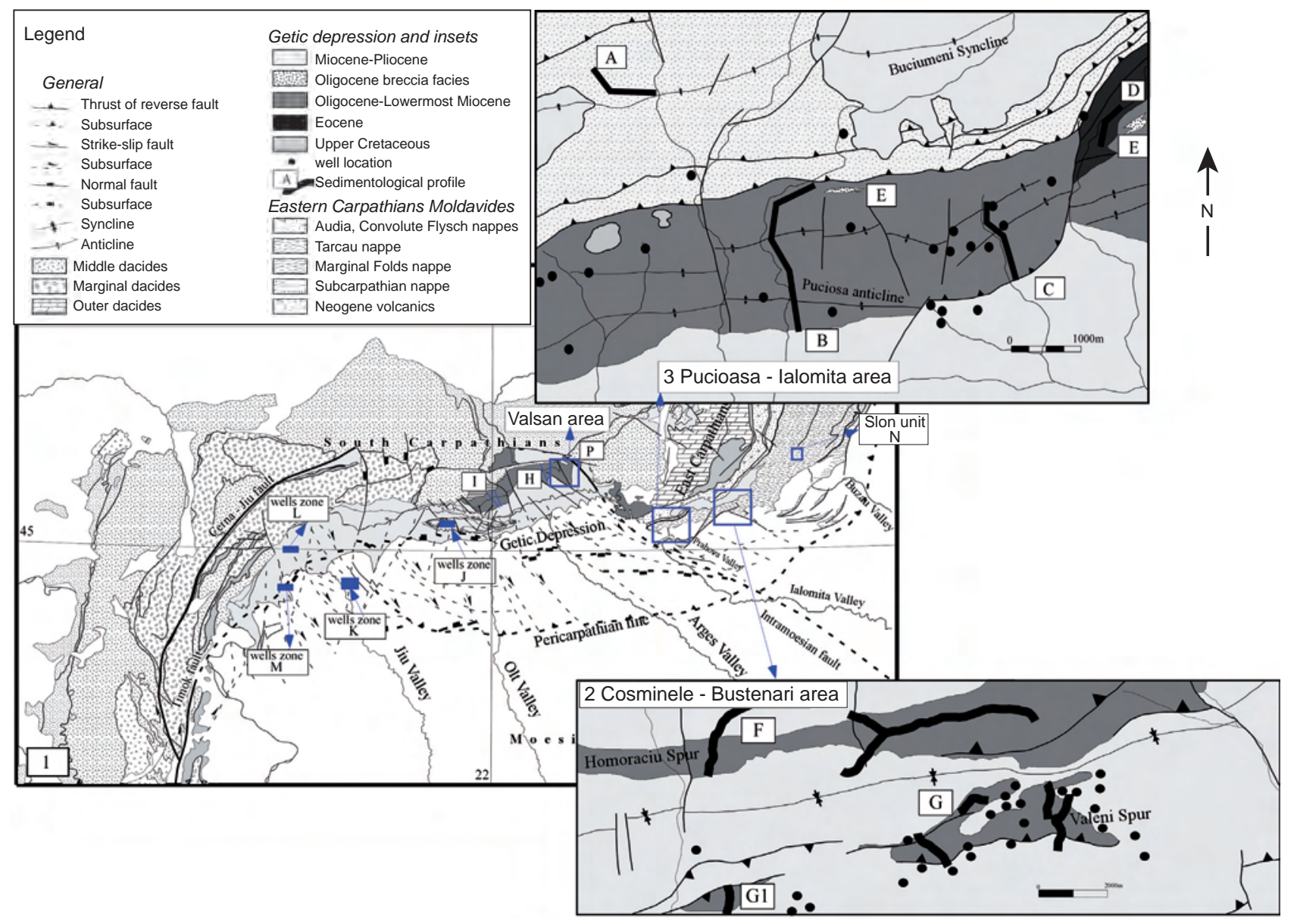

Figure 3

Detailed geological map 1) of the Getic Depression and Southeastern Carpathians compiled with elements from Sandulescu (1984), Stefanescu (1995), Rabagia and Matenco (1999), Tarapoanca et al. (2007), Roban (2008), Schmid et al. (2008), and Rabagia et al. (2011) and showing the working areas, various available data and specific geological maps for 2) the Cosminele-Bustenari and 3) Pucioasa-Ialomita zones. The indexed areas and points (A to $\mathrm{P}$ ) are further referred to and described in the text and the other figures.

F1 - Prograding units, high energy

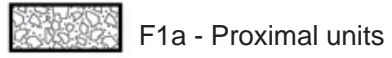

$\therefore$

in

F1b - Median units

F1c - Distal units
F2 - Transition, medium to low energy

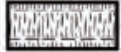

F2a - Transition, restrictive units (evaporites)

F2b - Transition units (shelf)
F3 - Aggrading units, dominantly distal, low energy

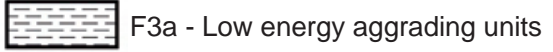

F3b - High energy aggrading units

F3c - Low energy (restrictive) units

Figure 4

General legend of facies associations.

\section{- Fla - Proximal Units}

The proximal unit association consists dominantly of meter-scale, clast-supported conglomerates and sandstones with well-sorted and rounded clasts. The individual members are characterized by fining-up tendencies, this feature being usually associated with basal erosional surfaces and decimeter-scale mud clasts. Meter-scale trough and tabular cross-bedding occurs in the units; channel filling and lateral accretion conglomerates are common as well. Subordinated thin parallel laminated marls occur with associated normal grading. Sandstone units occasionally reach meter-scale and display convolute and wavy laminations. 


\section{- Flb - Median Units}

Median units are characterized by sandstone beds interbedded with subordinate parallel laminated or massive siltstones. Basal erosional surfaces are rarely documented because they are filled with gravelly and pebbly sands. Mud clasts occur sporadically. Parallel lamination and massive structure are dominant, but low-angle tabular cross-bedding and gravelly channel-like bodies are also present. The pebbles are better sorted and rounded than in the proximal fans F1a. Rippled surfaces are more common here than in the previous units.

\section{- Flc - Distal Units}

The last and more distal association is silty and sanddominated. Although the marls are still subordinated, parallel laminated marls units can reach meter-thick scale. The marly units are interbedded with massive fining-up silty sands, reaching over one meter thickness.

\section{- F2 - Transition, Medium- to Low-Energy Units}

This facies association comprises a wide variety of dominantly medium- to fine-grained sediments, controlled mainly by floatation mass transport (suspension settling). The main characteristics are the ripple marks and wave structures, as well as little to no channeling, parallel and hummocky laminations. Two main facies associations were separated within these units:

\section{- F2a - Transitional, Restricted Units (Evaporites)}

This association occurs only in the Lower Miocene sediments and is characterized by interbedded units of metric-scale tuffs, sandstones and subordinated rhythmic centimeter-thick gypsum and black shales, seldom interbedded siltstones. Wave ripple marks are rarely noticed.

\section{- F2b - Transition Units (Shelf)}

This association comprises sediments characterized by meter-scale, silty to fine sand-dominated units, interbedded with centimeter-thick marls. The sand units are built up by cyclic couplets of light/dark layers, recording millimeterscale parallel lamination. Tangential, wavy laminations and wave-formed ripple marks can be documented. Millimetric coal layers and small-scale sand-filled channels are present towards the upper parts of the sequences, within the marly units.

\subsection{F3 - Aggrading Units - Dominantly Distal, Low Energy}

This facies association comprises a wide variety of dominantly fine aggrading sediments with subsequent erratic coarser layers controlled by both mass-flow and channeling type (stream- flow) transport building altogether a larger-scale aggrading unit. The main characteristic is represented by a continuous low-energy regime disrupted by spikes of intense energy recorded by coarse, often unorganized units. This unit was further divided into three main facies associations:

\section{- F3a - Low-Energy Aggrading Units}

These units are dominated by dark-gray slightly dysodilic (dysodiles are organic-rich, very finely laminated, paperlike pelites) marls of metric-scale and subordinated centimetric silty sandstones. The layers are sometimes centimetric and consist of alternations of calcareous red and gray marls with millimeter-thick interbedded sandstone. Subordinated silty sand units reaching rarely half a meter thickness, dominated by parallel and convolute lamination, are also documented.

\section{- F3b - High-Energy Aggrading Units}

This association consists of interbedded, decimeterscale units of massif sandy to silty units and parallel-laminated metric-scale gray marls. Although erosion is not clear at the bottom, a coarser character can be depicted sometimes at the base of the sandy layers which can reach up to $0.5 \mathrm{~m}$ thickness being normally graded, mainly with parallel lamination at the base, which is replaced upwards by convolute structures. Flute casts are common. Interbedded dysodilic marls also occur within the sequence.

\section{- F3c - Low-Energy (Restricted) Units}

Centimetric successions of dysodilic marls and/or black shales with gray marls have been identified. The black shales are partially sulfur-rich. Fish remnants have been observed locally near the top of the dysodilic beds. Thinbedded sandstone layers are sometimes intercalated within the sequence. Patchy menilite layers (organic-rich siliceous rocks) occur as well.

\section{DATA AND LOCAL INTERPRETATIONS}

We focused our field work and observations on three key areas aiming to unravel the existing relationships among the various Eocene to Lower Miocene litostratigraphic units (Fig. 2): the Valsan river basin for the study of the Olanesti marls, and Cheia, Corbi and Bradulet formations, the Pucioasa-Ialomita valley for the study of the Lower Oligocene marls (Lower Dysodilic Schist formation), and Pucioasa and Fusaru formations, and the CosmineleBustenari area for the study of the Pucioasa, Vinetisu, Podu Morii, Upper Kliwa, Bustenari, Cornu and Brebu formations (Fig. 3). 


\subsection{Valsan Valley Area}

This area lies near the easternmost limit of the Getic Depression (Fig. 3). It comprises good Eocene to Oligocene outcrops. As the Eocene-Oligocene sedimentary log was already described and dated by Roban and Melinte 2005 (Fig. 5), this zone will be analyzed by simple cartographic means focusing on the stratal relations of the Eocene to Oligocene units in order to understand the geometrical and, by consequence, stratigraphic relationships among the various facies associations.

Although there has been a long debate regarding the precise time equivalence of the Eocene-Oligocene formations cropping out between the Arges and Valsan valleys (Roban, 2008 for references), most authors agreed upon a five unitsbased correlation scheme. From bottom to top, it comprises the Calimanesti conglomerates (Lower Eocene, Jipa, 1982, 1984), overlain by the Middle to Upper Eocene Olanesti marls (Popescu et al., 1976), the Oligocene being recorded by the Cheia conglomeratic formation (Popescu et al., 1976), the Corbi sandstones (Bombita, 1980) and the Bradulet (Pucioasa-like) marl formation (Roban, 2008). Roban and Melinte (2005) have separated within the Eocene-Oligocene sedimentary record from the Valsan valley two coarse units, characterized by a dominancy of F1a and F1b high-energy facies: the Lower Eocene Calimanesti conglomerates and the Upper Eocene(?)-Oligocene Corbi Formation; and two units dominated by fine-grained, low-energy F3a facies association: the Olanesti and Bradulet marls (Fig. 5). The boundaries between these units are either normal when the finer units follow the coarser ones, or unconformable at the base of the coarser units. The unconformity at the base of the Oligocene sandstones and conglomerates is proved by the missing nanoplankton biozone NP22 (Roban and Melinte 2005), but the character of this unconformity must be precisely stated.

The geological map of the area (Fig. 5) displays two different zones. The northern part (mainly Eocene conglomerates and marls) is characterized by relatively monotonous S-dipping strata, with dips of around 15-20 degrees. Within the Upper Eocene and Oligocene formations cropping out in the southern part, two structural trends can be delineated: an E-trending anticline affecting the Oligocene conglomerates and a few more discrete NW-trending structures developed within the Oligocene-Miocene Bradulet Formation. The outcropping core of the asymmetric anticline is made up by a conglomeratic unit built up mainly by F1a and F1b facies association and characterized by steep-dipping strata (40-80 degrees), the steeper angles being measured on its northern flank. This asymmetry is further proved by the significant differences in strata dips recorded in the overlying unit. The coarse unit - the bulk of the Corbi sandstone formation - is clearly unconformable and truncates the underlying conglomerates (Cheia Formation), as indicated by the significant differences in the dipping attitude of the beds: from 40 to 80 degrees down to 10 degrees in the northern syncline and 20 degrees to the south. Although most authors (Roban and Melinte, 2005 and references therein) have assimilated both units into a single formation - the Corbi sandstone - we assume that the lower, deformed unit is coeval with the Cheia conglomerate, partially eroded and covered by the Corbi sandstone. When comparing the northern, undeformed part of the map with the bedding attitude in the anticline area, and assuming a 5-degree value for the initial pattern of sedimentation, we can depict a younger, general S-oriented tilting of around 10-15 degrees for the entire area. This amount must be added to the tilt of north-dipping strata and subtracted from the tilts of the southern ones in order to get the initial bedding attitude of the syntectonic conglomeratic layers.

The south-eastern part of the mapped area is characterized by a general NW-SE structural trend, recorded both by strata dips and small-scale folds developed within the youngest outcropping formation (Oligocene-Miocene Bradulet marls). Based on the bed positions and the information provided by the well drilled south of the anticline (Fig. 5), a roughly Etrending faulted growth anticline (backthrust orientation relative to the dominant structural vergence) is recorded by the coarse syntectonic, high-energy units overlying an erosional truncating unconformity. The nanoplankton dating (Roban and Melinte, 2005) indicates that the structural growth of this anticline started in the Upper Eocene to Lower Oligocene (NP21 zone) and ended in the Lower Oligocene (NP23 zone), the structure being sealed by the Corbi Sandstone which acts as a post-tectonic unit.

The next deformation that created the more discrete NWtrending postdates the deposition of the Bradulet Formation (Lower Miocene) and likely relates to the Miocene dextral strike-slip deformations documented within the Getic Depression (Rabagia and Matenco, 1999). This is suggested by the fold orientation, which is common within this basin, and by the lack of eastwards continuity of the main anticline. The regional 10-15 degrees tilting is even younger as this dip range can be noticed over the entire map.

\subsection{Pucioasa-Ialomita Valley Area}

This area was chosen aiming to understand the stratigraphic relations among the Oligocene-Miocene formations (Fig. 2, 3), including the Lower Dysodilic Formation, the Pucioasa marls and the Fusaru sandstones (Stefanescu, 1995), located at the junction between the Getic Depression and the Moldavides. The area was also studied to correlate the Eocene-Oligocene units described in the Valsan valley and westwards with those forming the Moldavides system.

In the Ialomita valley basin, the Eocene to Miocene sediments are already subdivided into five main formations, 

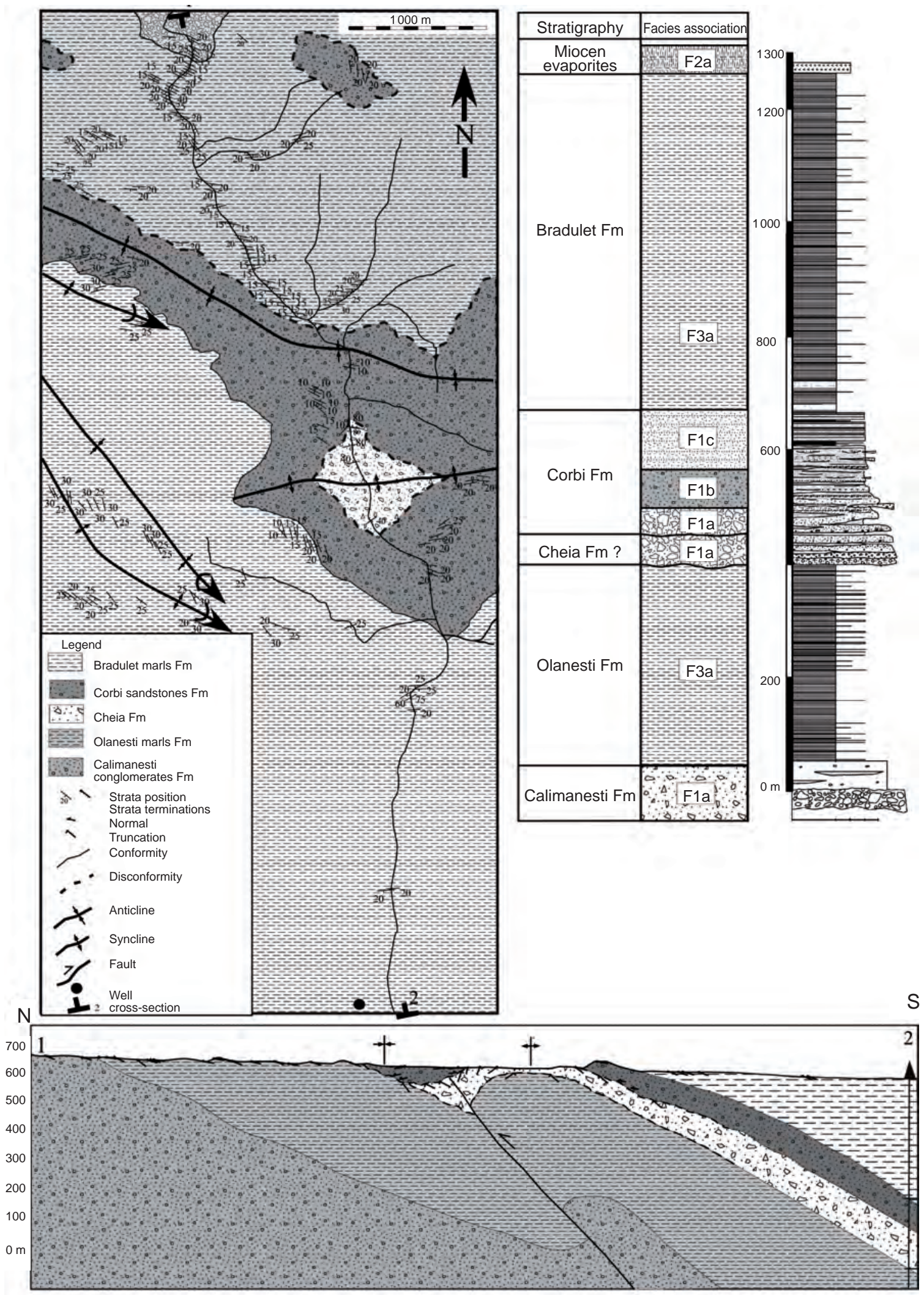

Figure 5

Valsan valley area geological map (Location P in Fig. 3), cross-section and sedimentary log. The map was rebuilt and reinterpreted after field work starting from the initial detailed maps of Morariu and Teodorescu (1988), in Roban (2008). For the facies association legend see Figure 4 . 
i.e. the Sotrile beds (Eocene), the Lower Dysodile schists spanning the Lower to Middle Oligocene, the Fusaru sandstones and the Pucioasa marls, assigned to the Oligocene to Miocene, and the Miocene gypsum formation (e.g. Stefanescu, 1995). Many authors (e.g. Stefanescu, 1995; Melinte and Brustur, 2008, and references therein) consider the Pucioasa marls and the Fusaru sandstones as coeval facies of the same formation covering more or less the NP24 to NN1 nanoplankton zones.

There is no continuous outcropping profile in this area to study the entire Eocene to Miocene sedimentary record. Instead, there are a few well-exposed valleys where detailed sedimentological observations were performed for various formations and units. The assemblage of all these observations was facilitated by the use of existing wells, the limited tectonic deformation and the fact that all observations are distributed within a less than $4-5-\mathrm{km}$ distance (Fig. 3). The Eocene to Lower Oligocene sedimentary log was built based on the almost continuous outcrops of the Crevedia valley (Fig. 3, 6). The Eocene Sotrile Formation (Fig. 6), exposed over a total stratigraphic thickness of $350-400 \mathrm{~m}$, is dominated by finer sediments, starting with the basal F3a-type units - showing low-energy, distal characteristics (alternations of calcareous red and greenish marls with millimetric interbedded siltstones), followed by an intermediate higherenergy F3b-type unit - recorded by the increasing thickness and frequency of the sandy units (individual thickness can reach 1-2 m), more or less interbedded with subsequent F3a marly units. The upper part of the Eocene is recorded by F3c, restrictive marine units (typical dysodiles) considered as indicating the beginning of the Oligocene.

The Oligocene-Miocene units and their interrelations were observed along two profiles in the Bizdidel and Valea Rea valleys (Fig. 3). The Bizdidel valley, located parallel to the Ialomita valley, constitutes the longest Oligocene profile in the area, with good and roughly continuous exposures, but it is affected by a few anticlines and synclines. The most important anticline is the Pucioasa anticline (Fig. 3), separating the profile into two parts. The technique used in this case consisted of building two individual sedimentary logs for each flank of the anticline and correlating them afterwards to create a synthetic $\log$ for the entire profile. The main difference between the two flanks relates to the facies associations in the median to upper part of the sedimentary section. In the north, above the Lower Oligocene marls and low-energy F3a-type associations, a relatively thick $(200 \mathrm{~m})$ coarser unit sits above an erosional unconformity surface - as proved by the high frequency of marl clasts filling the channel-shaped conglomerates (Fig. 6). These higher-energy facies associations, changing from proximal (F1a) to distal (F1c), were previously separated as the Fusaru sandstone formation. The end of the northern profile marks the return to low-energy, marl-dominated associations (F3a $+\mathrm{F} 3 \mathrm{c})$, which were assumed as representing the bulk of the Pucioasa marl formation by previous authors (e.g. Stefanescu, 1995). Although the southern flank preserves the same general features (i.e. lower part formed by low-energy units followed by median coarse units F1b and F1c, and finally the low-energy association F3a of the Pucioasa marls), we noticed differences between the two flanks mainly related to the reduced thickness of the high-energy units and the frequency and thickness ratios of the proximal/distal facies associations. For instance, the southern flank appears to record more distal facies associations. By reassembling the two flanks in a single sedimentary $\log$ (Fig. 6), a total stratigraphic thickness of $500 \mathrm{~m}$ was estimated for the Oligocene to Miocene sediments cropping out in the Bizdidel valley. The general sedimentary pattern is defined by the vertical stacking of low-energy units (Oligocene Lower Dysodile Formation), followed after an erosional hiatus by high-energy sandstones and conglomerates (Fusaru facies) and ending with a gradational return to distal or restricted low-energy units (Pucioasa marls). Miocene sands, tuffs and evaporites comprise the top part of this stratigraphic profile and truncate the upper Pucioasa marls.

The second Oligocene profile Valea Rea (Fig. 6) is located in the eastern part of the Ialomita-Pucioasa area (Fig. 3) in the vicinity of an oil field. It offers excellent outcrops for the Oligocene units, with good subsurface control in existing wells. It is a key profile for understanding the relationships between the Oligocene high-energy associations (Fusaru facies) and the low-energy ones (Lower Dysodiles and Pucioasa marls). Apparently, the profile indicates a significant thickness for the high-energy coarse associations (F1a to F1c - Fig. 6, 7). In the first $1.5 \mathrm{~km}$ of the surface profile only coarse sandstones and conglomerates are continuously cropping out, with a dominant dip of 10-15 degrees towards the S-SE (Fig. 7). The Lower Oligocene low-energy units are recorded in the southernmost part of the profile and include a thin restrictive F3c distal unit. The marl beds dip towards the north and are characterized by higher values, amounting to 20-25 degrees. Applying a simple estimate of geological thickness based on strata dips led to a more than 600-m thickness for the coarse unit, even taking into consideration a basal unconformity. The few small anticlines and synclines cannot compensate for this apparent thickness. The wells drilled within the adjacent oil field indicate instead a maximum thickness of 150-200 $\mathrm{m}$ for the coarse Oligocene series, being apparently inconsistent with the outcrop data. The two data sets can be reconciled if a progradational surface is considered between the coarse units and the subjacent marls. Then, the vertical thickness of the coarse units can be estimated at around $200 \mathrm{~m}$ in the north decreasing to $100 \mathrm{~m}$ in the south, which is consistent with the subsurface data (Fig. 7).

The well data also indicates intense reverse faulting at Eocene and Lower Oligocene levels (Fig. 7). These reverse faults duplicate the Eocene sandstones belonging most likely to the same association (F3b type), as in the Crevedia valley 


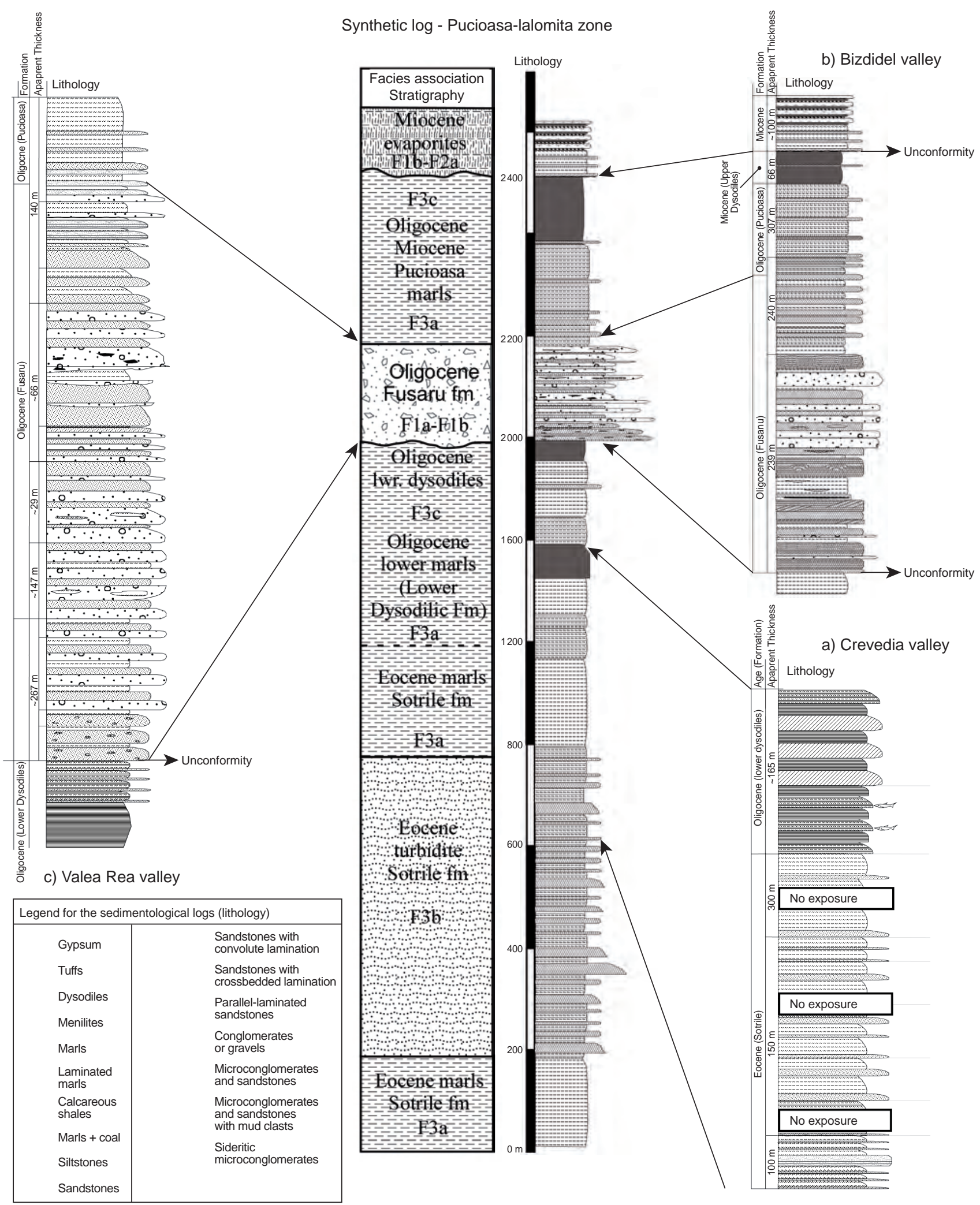

Figure 6

Pucioasa-Ialomita valley area (geological map in inset 3, Fig. 3), sedimentary logs - locations A, B, C and E in Figure 3, inset 3 and synthetic $\log$ for the area. For the facies association legend see Figure 4. 

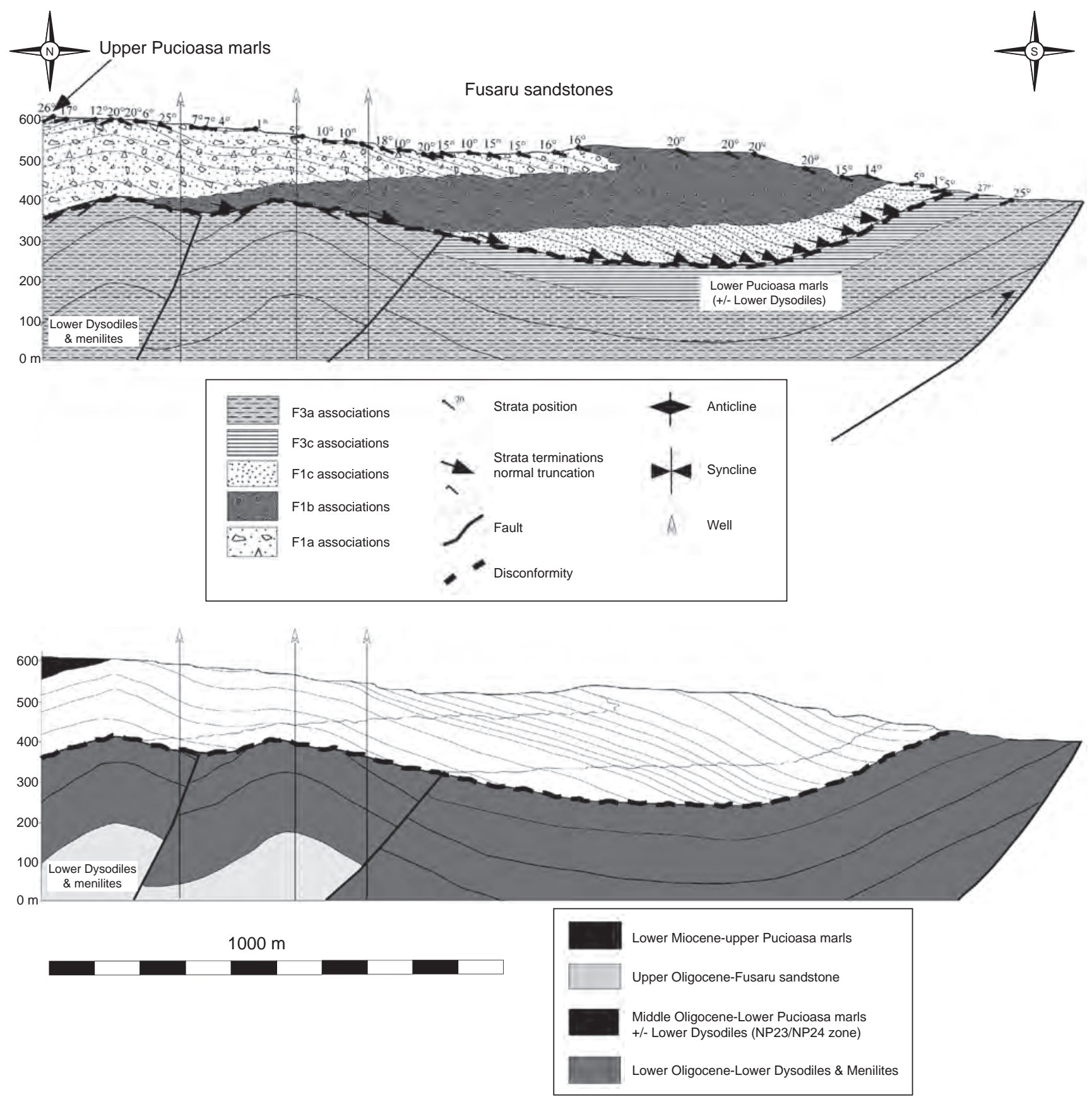

Figure 7

Pucioasa-Ialomita valley area (geological map in inset 3, Fig. 3), sedimentary and geological profile along the Valea Rea valley : location C in Figure 3, inset 3.

profile (Fig. 6). Although gentle anticlines are documented within the Fusaru Sandstone (Fig. 7), none of the deeper faults or steep structures was observed in the outcropping coarse sediments. Only the lower marls (southernmost part of the profile) are affected by stronger deformations. These facts indicate the existence of two structural stages separated by the progradational surface - the Fusaru sandstones recording less deformation than the subjacent formations which were deposited as post-deformational units truncating the Lower Oligocene marls (Fig. 7). Later deformations affected both units as indicated by the frontal thrusting, the anticlines involving both the Fusaru layers and progradational surface.

From a sedimentological standpoint, the OligoceneMiocene sedimentary record along the Valea Rea valley 
starts with low-energy marls and shales - F3a type, followed by large-scale prograding coarse, high-energy facies associations progressively changing from distal to proximal units (F1c to F1a). A well-developed polymictic breccia level containing Upper Cretaceous to Lower Oligocene-derived, centimeter- to meter-scale grains (Slon-type breccia, description after Stefanescu, 1995) is documented as an eastwards lateral equivalent of the Fusaru series (a few kilometers from the Valea Rea profile - Fig. 3, location E). The uppermost part of the Oligocene to Miocene sediments (i.e. Pucioasa marl formation), less developed in the Valea Rea profile, is confined to some tens of meters-thick low-energy F3a-type units: marls and silts at the northernmost part of the profile (Fig. 6, 7). The upper contact of the Fusaru Sandstone with the Pucioasa marls seems to be gradational.

By assembling all the sedimentary logs and using well data control, a synthetic Eocene-Miocene lithostratigraphic column was built for the Ialomita area (Fig. 6). The bulk of the entire sedimentary record is made up of low-energy distal or restricted units (F3a - F3b units) with an outstanding exception - the Fusaru Sandstone, which comprises highenergy coarse prograding bodies, truncating the subjacent units. The Fusaru Sandstone occurs in the Upper Oligocene (NN24 zone, after Melinte and Brustur, 2008) and grades upwards and laterally towards the low-energy units of the Pucioasa marls. We interpret this pulse in the basin sedimentary energy as a result of a tectonic deformation. This is substantiated by the structural differences beneath and above the Fusaru basal unconformity and by the strong documented erosion - in situ exposure and erosion of sediments down to the Cretaceous (Maastrichtian flysch). The removal of almost $1000 \mathrm{~m}$ of Paleocene to Oligocene overlying sediments is difficult to envisage without significant tilting and uplifting. This deformation was observed in the same area by Stefanescu (1995), who described the evolution of a local structure (Buciumeni syncline) and evidenced a tectonic movement that occurred before the deposition of the Upper Dysodile level and was followed by a second, Lowermost Miocene deformation. However, despite the evidence, these events were considered of limited extent, whereas the Slon breccias were interpreted as sedimentary-driven olistostromes.

Comparing the Eocene to Oligocene sedimentary record of the Ialomita area with the previously described Valsan valley brings up two significant differences:

First, the Eocene conglomerates largely developed within the Valsan valley do not have any counterpart in the Ialomita zone. Second, we still lack the lateral traceability of the two Oligocene events. Although the lower Oligocene high-energy event recorded by the Cheia-Corbi coarse units (Valsan area) is very similar to the Fusaru unit (Ialomita area), also representing high-energy sedimentary pulses with associated syn- to post-tectonic character, these two events seem to be distinct. The Cheia-Corbi units are eroding the Eocene marls (NP21 zone) and were most likely deposited during the NP23-NP24 stages, whereas the Fusaru units are incising the Lower Oligocene marls (NP22 to NP23 zones) and rather cover a NP24-NP25 zone time span.

\subsection{Cosminele-Lupa Valley Area}

The work done in this area was focused on the relationships among the various formations previously separated within the uppermost part of the Oligocene to the Lower Miocene (pre-evaporites) in the southern Moldavides (Fig. 2, 3). These formations comprise the Vinetisu, Pucioasa, Podu Morii, Bustenari-Upper Kliwa and Upper Dysodile formations (the Lower Dysodile formation does not crop out) (Patrut, 1955, in Bucur et al., 1968). Two roughly E-W-oriented antiforms belonging to the Tarcau nappe were identified and characterized by different Upper Oligocene-Lower Miocene sedimentary records: the Homoraciu and Valeni spurs in the north and south, respectively, with a predominance of the finer facies in the Homoraciu spur. Three sedimentary logs were built, one in the Homoraciu spur and two in the Valeni spur. Unfortunately, due to later deformations only a few sedimentary contacts between the various formations could be found and described.

The sedimentary record of the Homoraciu spur is almost continuously cropping out from the Oligocene to Lower Miocene on the Lupa valley (Fig. 3, 8). The base of the Oligocene sedimentary units cannot be observed being represented by a tectonic contact. The Oligocene is developed as dominantly fine facies whereby the pelitic decimeter-scale, parallel-laminated intervals (marls, some dysodiles) overcome the interbedded silty sands which are scarce and thinner (centimeter-thick). As a whole, the Oligocene deposits reach around $1000 \mathrm{~m}$ of stratigraphic thickness. Most of this sequence was described as the Pucioasa marl formation (Stefanescu, 1995) covering the NP24 to NP25 zones (Melinte and Brustur, 2008). This unit is thrust over the Middle Miocene salt and marls. Therefore, it is unclear whether the profile also includes the Lower Dysodile Formation or not, as could be suggested by its significant thickness. The Pucioasa marls were deposited as low-energy facies associations, F3a-type followed by a more restrictive type (dysodiles, F3c type) (Fig. 8). The Pucioasa Formation is vertically and gradually replaced by sandier facies, indicating a slight increase in the basin sedimentary energy. These decimeter-scale silty sands interbedded with marls reach 120-m thickness and are interpreted as a high-energy aggrading facies association (F3b type - Fig. 8). They were previously separated as the Vinetisu Formation (e.g. Stefanescu, 1995) covering the NN1-NN2 zones (Melinte and Brustur, 2008). The Oligocene-Lower Miocene sedimentation continued with a low-energy restrictive association (F3c type) forming the Upper Dysodile Formation (NN2 zone - Melinte and Brustur, 2008). 

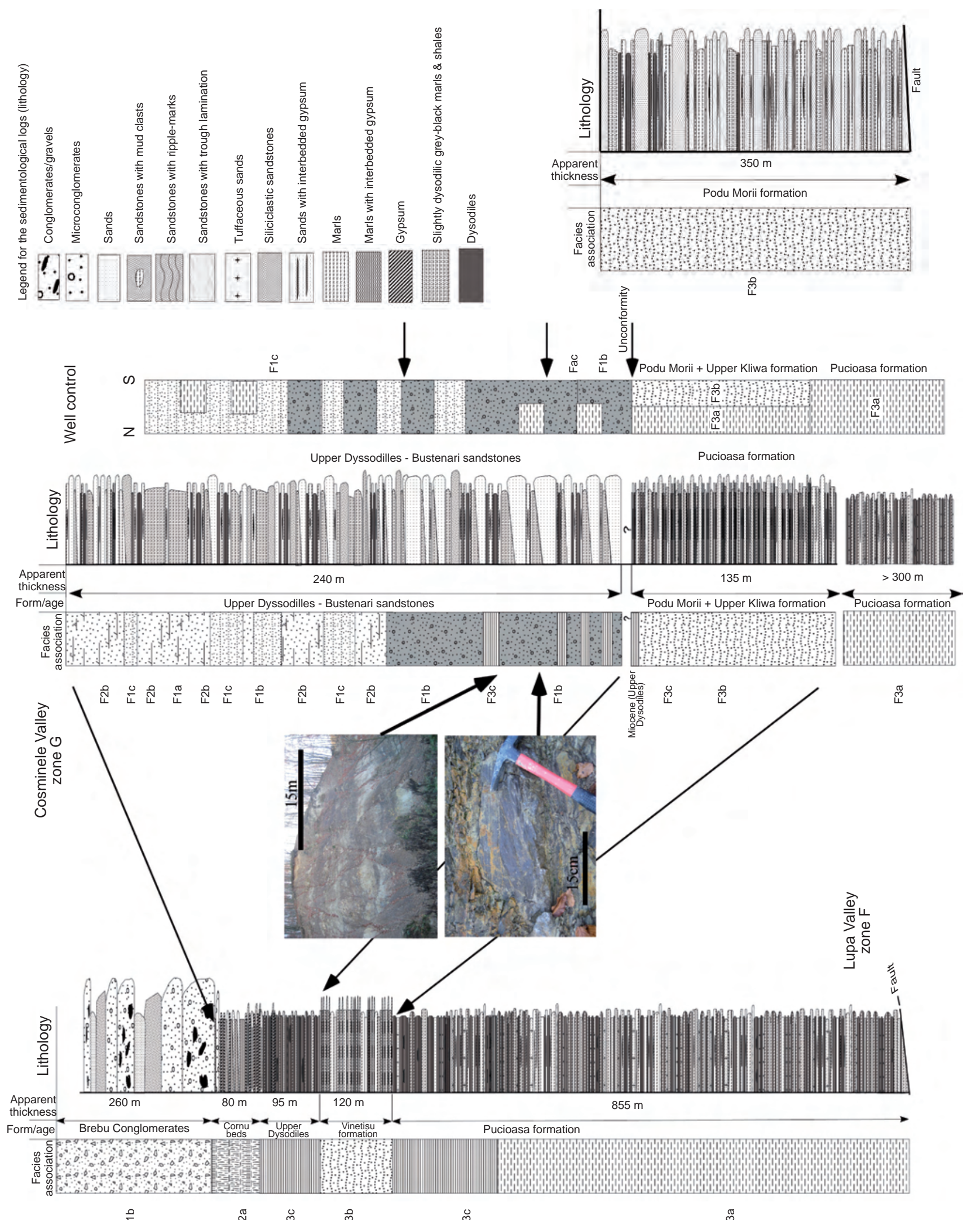

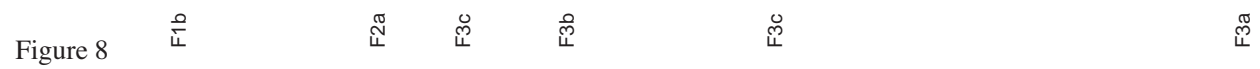

Bustenari-Cosminele area (geological map in inset 2, Fig. 3), sedimentary logs - locations F, G and G1 in Figure 3, inset 2. For the facies association legend see Figure 4. 
The dominating low-energy Oligocene-Lower Miocene sedimentation ends up with the transition to a restricted evaporitic-type association (F2a), represented by the Cornu beds (Bancila, 1958). Around 80-m-thick shales and silts with gypsum centimeter-scale thick layers crop out in the Lupa valley (Fig. 8). Gradually, the Cornu beds low-energy units are replaced by coarser facies, dominantly conglomerates and sandstones (Brebu conglomerate formation - Bancila, 1958). Over 250-m-thick F1b-type associations are recorded towards the top of the Lupa profile (Fig. 8).

In the southern Valeni spur the Oligocene to Lower Miocene sedimentary record is less continuous and more fragmented than in the northern one, mostly due to younger deformations. The relatively high number of wells drilled in the area, to a certain degree, compensates for the lower quality and continuity of outcrop information. A synthetic sedimentary $\log$ was reassembled from different outcrops, fortunately located within relatively short distances (less than $5 \mathrm{~km}$ ) and also from the logs of the wells drilled in the area (Fig. 8). The most important feature characterizing the southern sedimentation area (Valeni spur) relates to the development of a large-scale (over $200 \mathrm{~m}$ thick), quartz-dominated formation, previously described as the Bustenari Sand (also referred to as a correspondent of the Upper Kliwa Formation, Stefanescu, 1995; Rusu et al., 1996). The contact of this unit with the underlying sediments, either F3a facies associations previously described as the Pucioasa Formation or the Podu Morii Formation - which is coarser and better expressed as a typical F3b high-energy unit, sometimes referred to as the Upper Kliwa (Bucur et al., 1968) - has not been observed in outcrops. However, the well logs suggest a sharp, most likely erosional contact between the coarse, hundreds-of-metersthick Bustenari Sand and the underlying finer sediments. This contact changes its character northwards where interfingering of finer, hundreds of meter-scale units (Upper Dysodiles and Podu Morii - Kliwa type) with the coarser Bustenari sands are common (Fig. 8). The Bustenari Sand shows the typical features previously described as the highenergy prograding facies associations (F1a, b and c): limited lateral correlativity, erosional surfaces, soft clasts made of shales and dysodiles, and tabular lamination. Individual channels, eroding each other or the interbedded dysodilic shales and marls can reach 3-6-m thickness and are characterized by an impressive lithological homogeneity (Fig. 8), being made of very well-sorted and clean quartzitic sands. The well $\log$ s indicate a large-scale (hundreds of meters) fining-upwards tendency for this unit.

By comparing the northern and southern sedimentary logs (Lupa valley relative to Cosminele/Telega valleys, Fig. 8) it can be noticed that both areas are characterized by comparable and correlable formations up to the Upper Dysodile Formation. In the north, this unit is followed continuously by the Cornu beds (restrictive F3c-type associations) and the high-energy F1a Brebu conglomerates, whereas in the south it is overlain by the high-energy associations of the Bustenari Sand. This points to the question of time relationships among the three formations. A contemporaneous age of deposition is difficult to envisage due to both lithology (it is hard to make a correlation between evaporites and poorly sorted conglomerates made up of clean, well-sorted quartzitic sands) and the distinct relationships among the Upper Dysodile Formation on the one hand, and the Cornu and Bustenari Sand formations on the other hand, which preclude a direct correlativity. Based on nanoplankton analysis, Rusu et al. (1996) suggested that the Bustenari Sand reaches the NN2 zone, beneath the Cornu evaporite (NN3 zone - Stefanescu and Marunteanu, 1980). Thus, a poly-phased deformation model is proposed (Fig. 9) to explain the sedimentary evolution of the area. This model assumes that sediment sources were located in two different positions within the basin, i.e. in a distal, intra-basinal source related to exhumed Kliwa quartzrich sandstone in the south (limited spatially, in a similar way to the Bustenari Sand) followed by a proximal, Carpathian source for the northern Brebu conglomerates. This model requires a pre-evaporitic tectonic event to create the intrabasinal source for the Bustenari Sand followed by the main deformation episode, belonging in the older terminology to the Old Styrian phase (cf. Sandulescu, 1984, 1998) which would be responsible for the uplift of the northern area. The two antiforms (Homoraciu and Valeni spurs) were created later during the post-Middle Miocene deformational phases as indicated by the overthrusting of the Middle Miocene evaporitic sequence in both areas (Fig. 8). This hypothesis needs further paleontological work to be validated. For the time being, we note that major sedimentary differences between the Valeni and Homorociu spurs relate only to the Early Miocene period, when the high-energy unit of the Bustenari Sand was deposited in a more distal part of the basin.

None of the previously described high-energy events represented by the Cheia-Corbi and Fusaru formations are recorded in the area. Another notable difference is related to the character of the contact between the Lower Miocene evaporite (Cornu beds) and the overlying formations. This contact is erosional in the Ialomita area, whereas it is gradational in the Homoraciu spur (Lupa valley).

\section{REGIONAL CORRELATION AND DATA INTEGRATION}

Based on this study and other outcrop data published by various authors, we attempted a correlation of the Eocene to Lower Miocene sedimentary events from the Olt valley in the west to the Prahova valley in the east (Fig. 3). Because virtually no Eocene-Oligocene outcrop occurs (with very limited exceptions) west of the Olt valley, we had to rely here on the few existing Oligocene-Eocene wells (from Rosu, 2005) to extend this correlation farther to the west. 

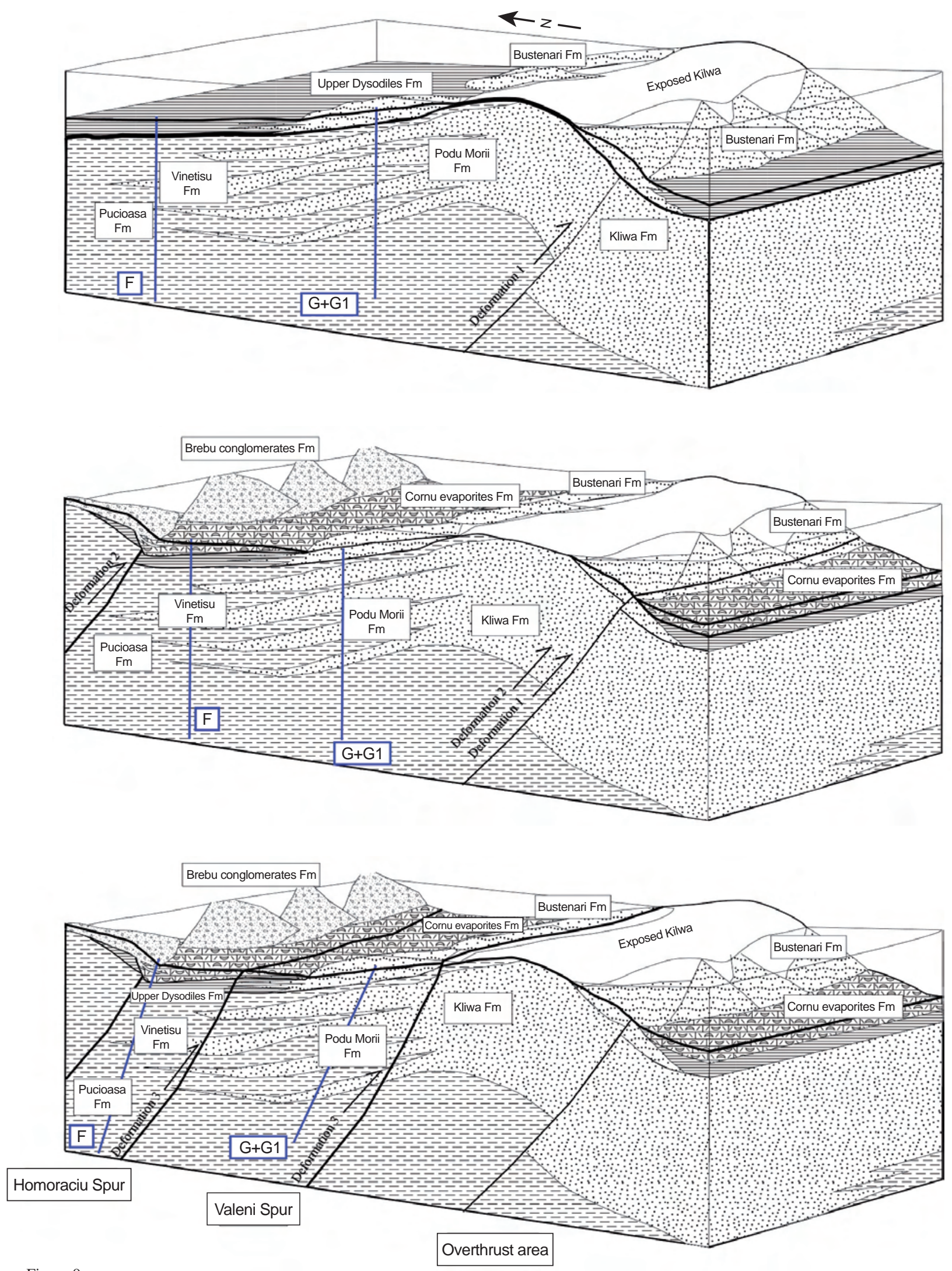

Figure 9

Tectonic evolutionary model for the Cosminele-Bustenari area (geological map in inset 2, Fig. 3). Detailed sedimentary logs for L, G and G1 in Figure 8. 
Roban and Melinte (2005) separated and dated four units within the Eocene-Miocene sediments cropping out to the west of the Arges valley (Fig. 3). Two formations are of high-energy type, dominated by sandstones and conglomerates, i.e. the Eocene Calimanesti conglomerates and the Oligocene Cheia conglomerates (originally introduced by Murgeanu, 1941, in Roban and Melinte, 2005). The two other formations of low-energy type are dominantly made up of marls and silts, comprising the Eocene to Lower Oligocene Olanesti marls (Murgeanu, 1941, in Roban and Melinte, 2005) and the Oligocene to Miocene Bradulet Formations (Fig. 10). Although relatively well defined in the literature from a lithological point of view, all these formations (except the Olanesti marls) are proved to be heterochronous (Roban and Melinte, 2005). The top of the Olanesti Formation varies from nanoplankton zones NP21 to NP22 (Fig. 10) as a function of the timing and amount of erosion occurring before the deposition of the overlying high-energy units, namely the Cheia conglomerates in the west and the Corbi Formation in the east. The base of the Upper Oligocene-Miocene marly Bradulet Formation is also diachronous, varying from the NP24 to NP25 nanoplankton zones (cf. Roban and Melinte, 2005), again controlled by erosion and further development of the overlying Cheia and Corbi formations.

These two high-energy units, the Cheia and Corbi formations, span the nanoplankton zones NP22-NP23 (the former) and NP23-NP25 (the latter), following Roban and Melinte's (2005) dating, thus being characterized by limited spatial extent. The relationships between the two have been identified in the Valsan valley as an angular unconformity. The transition of the Bradulet Formation is either normal with the overlying evaporite formation, when reaching the NN2 Miocene zone (Roban and Melinte, 2005), or comprises an erosional hiatus (Miocene conglomerates) down to NP24-25.

The eastern areas were previously described in the field with the exception of Slon breccia of the Slon Formation (Fig. 10), for which we used data from the literature. Initially, the Slon facies (Popescu, 1952) referred to all the highenergy breccia-type units located within the Pucioasa Formation. The Slon unit was described by Bucur (1966) as a high-energy unit (breccias and conglomerates) eroding the upper part of the Pucioasa marl formation in the Siriu valley (map of Fig. 3). The Slon unit is made up of breccias and conglomerates containing Eocene to Oligocene meter-scale clasts with an associated shale matrix. Interbedded dysodiles and evaporites are also documented within this unit, indicating that the Slon unit was most likely deposited during the NN1 to NN2 zones, though its relationships with the evaporite remain unclear (Fig. 10).

A significant confusion, which has been perpetuated over time and diluted the clarity of the existing correlations among Eastern and Southern Carpathian Oligocene to Miocene formations, relates to the mixing of the concepts of facies, facies associations and formations. As stated before, the Slon breccias were defined as both a facies association and a chronostratigraphic unit by Bucur (1966) within the Buzau area (location in Fig. 3). However, the same name describing only the facies association with different chronostratigraphic positions was also used to refer to almost all the high-energy breccia-type facies associations within the Upper Oligocene to Miocene sediments (Joja, 1952; Popescu, 1952; Bucur, 1966; Stefanescu, 1995) - an example being the use of the Slon facies name for the breccias described in the Pucioasa area at a different stratigraphic location than the originally introduced Slon unit (Fig. 10). The same confusion occurs with the use of the Fusaru name when describing both a highenergy facies association and a chronostratigraphic unit located within the Pucioasa Formation in the Ialomita valleyPucioasa area (Fig. 10). Stefanescu (1995) extended it to all the sandstones intercalated within the Pucioasa marls other than the Kliwa quartz-rich type (also Popescu, 1952; Grigoras, 1955; Patrut, 1955 in Bucur et al., 1968), disregarding the chronostratigraphic position and employing the term of Pucioasa marls with Fusaru-type sandstone formations. Most likely, the sandstones interbedded within the Pucioasa marls and described as Fusaru-type sandstones in the eastern areas are in fact made up of a F3b-type facies association, normally grading to the distal Vinetisu turbidites. These Vinetisu turbidites are distinct from the high-energy prograding F1a-F1c facies associations of the Fusaru unit, which rather relate to the Cheia, Corbi, Bustenari and Slon units (Fig. 10).

There are few data available regarding the extent of the Oligocene series west of the Olt valley, most of them being concentrated on the so-called Romanesti uplift (Rabagia and Matenco, 1999). Farther west, the well data (from Motas, 1983; Rosu, 2005) indicate an important change in the Eocene-Oligocene facies (Fig. 10). Between the Olt and Jiu valleys the Olanesti and Bradulet marly formations are still present, but with a significant reduction in thickness (less than $600 \mathrm{~m}$ for both). However, the Miocene erosion cannot be held responsible for such thickness variation, because the Miocene evaporites are documented near the top of the Bradulet Formation. A limited (less than 100-m-thick) and discontinuous, high-energy event separates the Olanesti and the Bradulet marls. Farther west, deep wells document the total disappearance of the Eocene Olanesti marls which are replaced by up to 700 -m-thick conglomerates, also partially covering the time span of the Olicocene Bradulet marl formation, which in turn is reduced to around 150-m-thick marls and interbedded sandstones. Again, this thickness reduction cannot be accounted for by erosion because Miocene evaporites are documented as well. In the western part of the studied area (Motru valley - Fig. 10), only conglomerates are documented, but they are strongly affected by the Miocene erosion. 


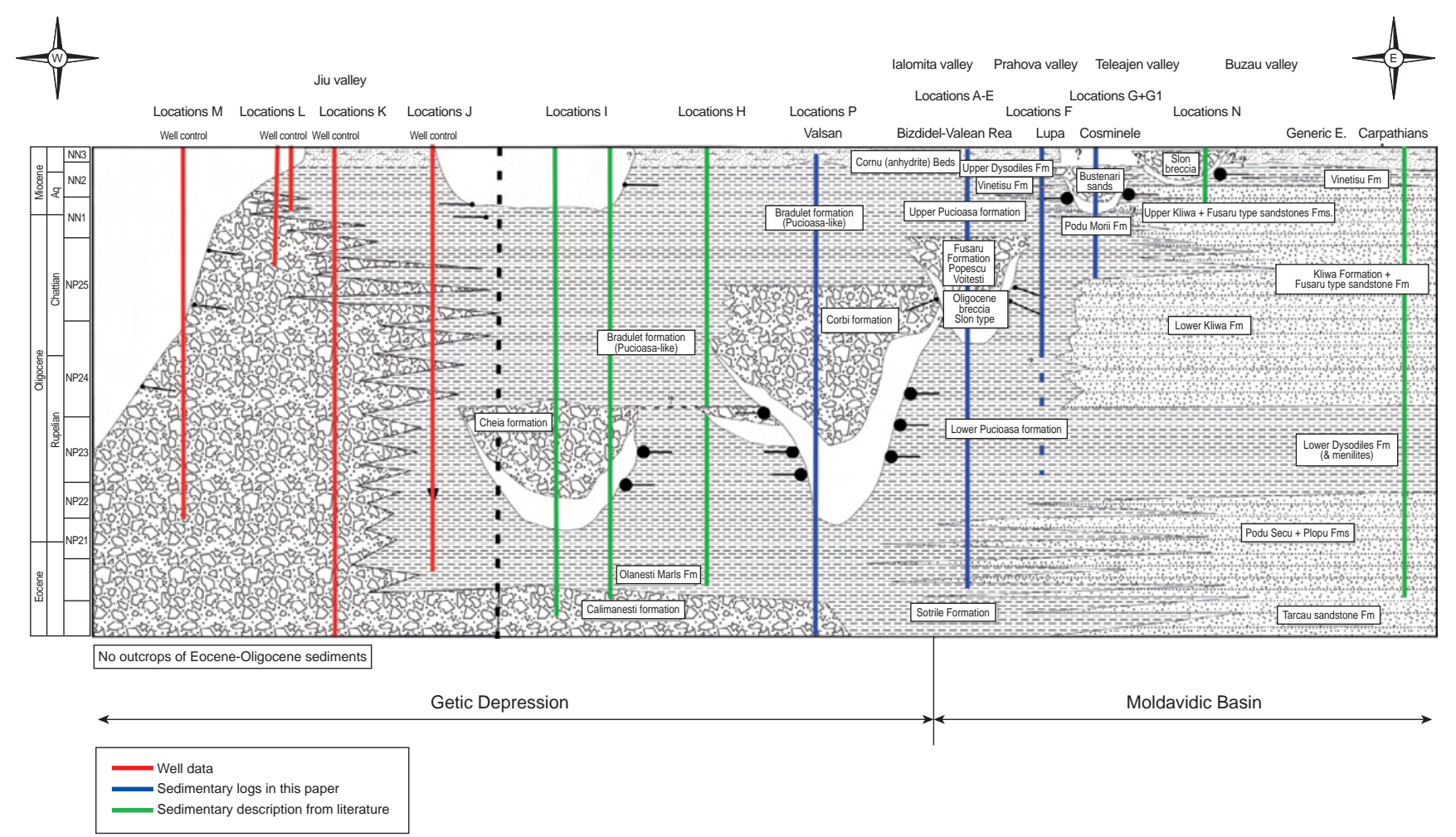

Figure 10

Chronostratigraphic chart of the Eocene to Lower Miocene sediments from the Getic Depression and Southeastern Carpathians (southern Moldavidic basin): the dominant facies association is depicted according to Figure 4. Locations of the sedimentary logs and wells can be found in Figure 3, detailed descriptions in the text and Figures 5, 6 and 8. Locations I and H are modified after Roban and Melinte (2005), location N after Bucur (1966) and the generic log for the Eastern Carpathians is compiled from various sources (Puglisi et al., 2004; Belayouni et al., 2009; Miclaus et al., 2009).

Although there are still issues to be addressed in the future - mainly related to the precise dating in the easternmost and western areas, all these data indicate the existence of two main types of facies associations within the Eocene to Miocene sedimentation, comprising both proximal highenergy prograding associations and distal variable-energy aggrading units.

The first type dominates the western zones of the Getic Depression, accounting for massive conglomerates (Fig. 10), whereas in the central and eastern zones it is documented at different times, accounting for the Calimanesti, Cheia, Corbi, Fusaru, Bustenari and Slon units, with limited spatial extent and eroding the other units. Due to their relationships with underlying sediments (significant incision) and the sedimentary characteristics in terms of clast provenance (breccias with Cretaceous to Oligocene flysch elements) all the latter units are interpreted as syntectonic units. If the western highenergy units are characterized by a retrograding tendency, the syntectonic units are migrating eastwards through time (Fig. 10).
The second type, distal sedimentary units such as the Olanesti, Bradulet, Pucioasa, Vinetisu, Podu Morii, Kliwa and Dysodile formations are developed in the central and eastern areas. They are characterized by a clear increase in energy eastwards (Fig. 10), i.e. Olanesti marls versus Podu Secu / Plopu formations, and Pucioasa marls versus Vinetisu, Kliwa, Podu Morii and Fusaru-type sandstones.

\section{CONCLUSIONS}

The occurrence of high-energy units within the EoceneLower Miocene sediments from the Southern and Eastern Carpathians has been documented for a long time (e.g. Popescu, 1952, 1958; Bancila, 1958; Bucur, 1966). They were first and for a long time assumed to result solely from sediment-controlled processes (submarine erosion, transgression) (e.g. Bancila, 1958; Sandulescu, 1984; Mutihac, 1990; Stefanescu, 1995) and then from eustatic sea level changes (Ryer, 1998). If the first interpretation lacks the process concept and has a more descriptive, local character, the second 
tries to provide a broader, process-related explanation for the occurrence of some of the Oligocene high-energy units. The eustatic assumption might be reasonable as long as the largely employed tectonic models (Sandulescu, 1988; Csontos et al., 1992; Matenco and Bertotti, 2000) consider this time span as tectonically mute (after Late Cretaceous contraction, all thrusting events making up the Outer Carpathian allochthon were considered Miocene in age, with younger reactivations only in the SE Bend zone).

In our view, the development of these sedimentary units lacks traceability, a key element required for the definition of an eustatic-driven event. As long as a sedimentary event has an extra-basinal, global cause, it should be recorded on a basinal scale. As previously demonstrated, the high-energy units described within the Eocene to Lower Miocene sedimentary pile are largely diachronous, migrating from EoceneOligocene in the west (Cheia conglomerates) to the Lower Miocene for the Bustenari and Slon formations (Fig. 10). Moreover, most of the high-energy units (Cheia, Corbi, etc. formations) are characterized by syn- to post-tectonic stratal relations with underlying units (angular unconformities) and some would imply hundreds of meters of erosion to account for their thickness (e.g. Fusaru, Slon formations). Therefore, the development of these high-energy units relates, in our view, to a contractional deformation that was migrating eastwards in time and created, rejuvenated or increased the unroofing and exhumation in the source areas.

During the past, not all scholars have agreed upon a tectonic quiescence during the Eocene-Lowermost Miocene times. For instance, Atanasiu (1958) interpreted the variation in the Oligocene facies and the occurrence of the high-energy units (Slon breccias) as recording a compression during the so-called Savic phase. Such Paleogene compression was also mentioned later by Stefanescu et al. (2006), although in their opinion the main post-Cretaceous shortening events shaping the present-day Carpathians occurred during the Early and Middle Miocene. According to Atanasiu (1958), compression was active from the Eocene to Upper Oligocene (including at the time the Lowermost Miocene as well, because the stratigraphic boundary was placed at the top of the Upper Dysodile Formation/base of the evaporitic units). Small (1959) also indicated more or less continuous deformations from the Upper Eocene to Lower Miocene conditioning the oil fields within the Tarcau nappe at the SE Carpathian Bend zone. More recent models (e.g. Sandulescu 1984; Mutihac, 1990) tried to simplify the regional evolution and discarded any Eocene to Lower Miocene shortening within the Carpathian nappe pile, the bulk of thrusting being assigned to the Styrian and post-Styrian deformations. Recent thermochronology data from the Southeastern Carpathians (Merten et al., 2010) also suggested the need to review the former models by documenting Paleogene to Lowermost Miocene exhumations within the Carpathian nappe pile.
Lack of any shortening during such a considerable time span as the Eocene to Lower Miocene period is also at odds with the reconstructions of the Tertiary tectonic transport of the Carpathian units along the Cerna/Timok fault system towards the final docking to the East European/Moesian foreland plate. Fugenschuh and Schmid (2005) pointed out the presence of a marine embayment closing progressively rather than in sudden and much delayed steps. Furthermore, the documentation of tens of kilometers of displacement along the Cerna wrench fault during the Oligocene (Berza and Draganescu, 1988; Fugenschuh and Schmid, 2005) and of a roughly similar order of magnitude along the Timok fault in the Latest Oligocene(?)-Early Miocene (Tarapoanca et al., 2007) requires a corresponding shortening in front of the advancing plate. The Early Tertiary evolutionary models of the Romanian Carpathians highlight the Eocene as a time of extension within the former Late Cretaceous tectonic assemblage, and the Oligocene as recording only dextral rotation of Tisza-Dacia blocks around the Moesian border (e.g. Fugenschuh and Schmid, 2005) without evidencing any accommodation structures at the frontal part of the orogen. Although frontal compression was mentioned in the internal Moldavides nappes (Convolute Flysch and Audia/Macla nappes) by Matenco and Bertotti (2000), their analysis (e.g. their Fig. 5) overlooked any further effects of Eocene-Lower Miocene deformations.

Without going too far in the interpretation of regional events, but driven by the sedimentary records of tectonic events occurring between the Eocene and Lower Miocene within the Carpathian thrust system, a more detailed tectonic evolutionary model at the contact between Tisza-Dacia and Moesia is proposed in Figure 11. As stated before, the western high-energy Cheia, Corbi and Fusaru units altogether record a deformation migrating eastwards from the NP21 to NP24 zones (Fig. 10). Taking into account the position of the Fusaru unit and associated breccias in the immediate vicinity of the Audia line (see Fig. 3, inset 3, location E), such eastward migration of the Paleogene deformation seems to have triggered the early start of the Tisza-Dacia block transport along the Cerna - Timok fault system, as suggested by the Oligocene initiation of the Petrosani basin (e.g. Nastaseanu, 1984; Fugenschuh and Schmid, 2005) and associated frontal compression. The eastward Oligocene position of the TiszaDacia block (north of Moesia) within the existing embayment was also suggested by Morley's (1996) reconstructions. This frontal compression determined the thrusting and uplift of the inner flysch nappes (Curbicortical flysch and Audia) within the intra-Carpathian embayment (Fig. 11), inducing the changes in basin sedimentary energy recorded by these sedimentary units. This assumption is consistent with the intra-Oligocene deformations observed in the Buciumeni syncline (location in Fig. 3, Stefanescu, 1995) even when integrated into a broader model. The eastwards and northwards extent of these initial structures and their impact within 
the frontal sediments (future Tarcau nappe) was probably limited to folding and faulting, as a function of available space in the embayment. Such regional distribution is consistent with the results of Puglisi et al. (2006) and Belayouni et al. (2009) and with the structural differences observed between the Pucioasa and Fusaru formations (Fig. 7).

As the Tisza-Dacia block was advancing eastwards, so did the strike-slip-type contact with Moesia, cutting and leaving behind part of the existing structures (Fig. 11). Contraction is recorded farther east by the Bustenari and Slon high-energy units. As previously described, the individualization of the two Tarcau nappe spurs, i.e. the Valeni and Homoraciu spurs, began during the Upper Oligocene and extended to Lower Miocene times (NN1 to NN2 biozones). This deformation, assumed to extend farther to the northeast (Belayouni et al., 2009), had a compressional character west to the Ialomita valley basin, as indicated by the unconformity described here between Miocene evaporites and Pucioasa marls, and changed to a strike-slip farther west (Fig. 11).

This model also explains the differences between the coarser Eocene to Oligocene facies recorded in the west (Fig. 10) relative to the finer ones in the east. It means that the basin changed laterally from a wide foredeep (flyschdominated) in the east Moldavidic basin (e.g. Belayouni et al., 2009), to a smaller, narrower, shallower and rapidly subsiding high-energy pull-apart-type Getic Depression in the west (Fig. 11). This implies that the main depocenter of the basin was not entirely following the Carpathian belt, but was confined to the frontal flexural part of the foreland, as indicated by the transport direction observed within the Eocene to Oligocene sediments (Jipa, 1966; Contescu, 1974).

The Miocene compressions, Old and New Styrian (Sandulescu, 1984, 1988), were confined to the remaining eastern embayment. They were related to the transtensional

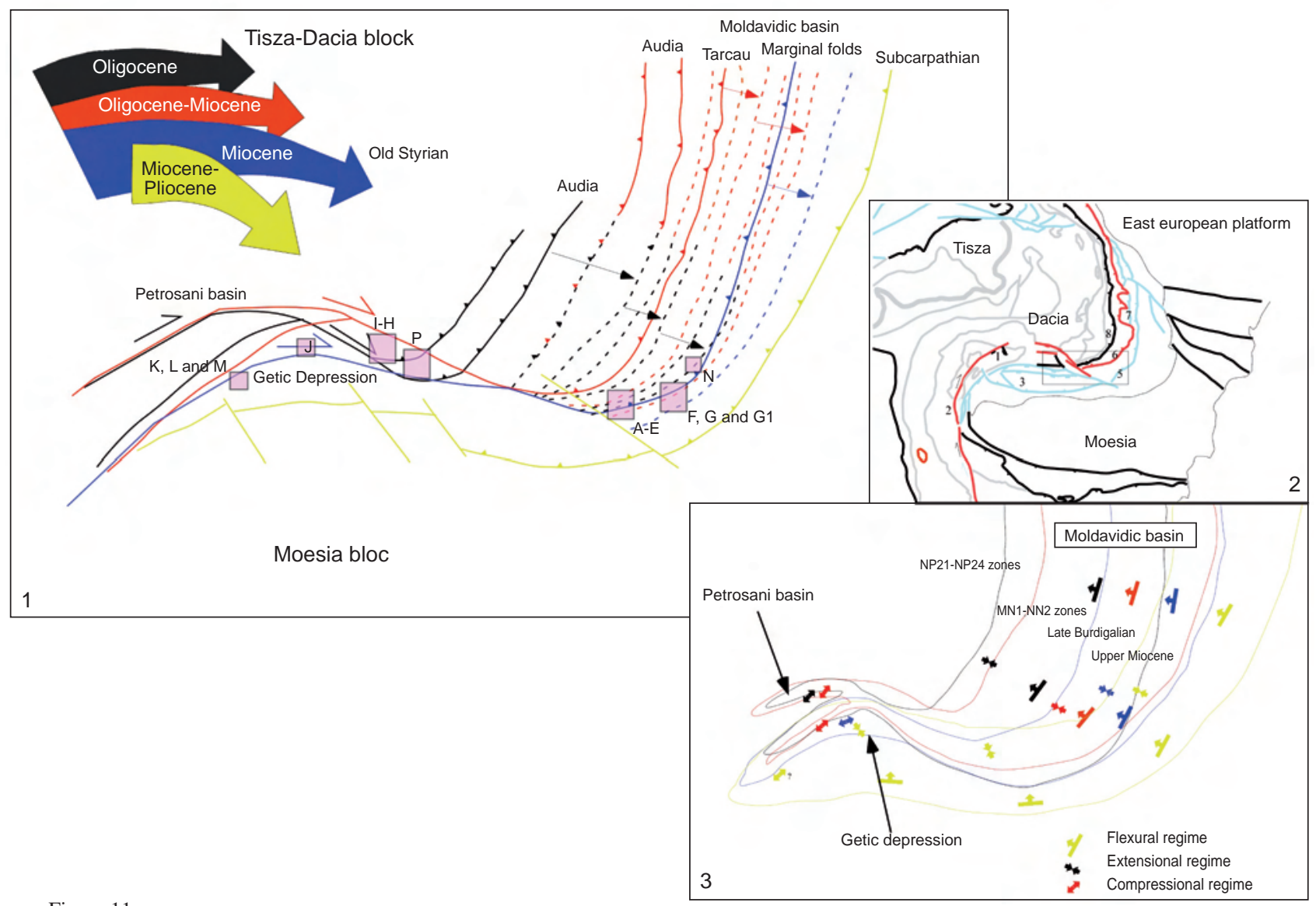

Figure 11

Oligocene-Neogene tectonic evolutionary model for the contact zone between Moesia and Tisza-Dacia blocks. Inset 1 depicts time evolution of the main tectonic lines documented in the area (today's position in inset 2) against available data (for locations A- P, see Fig. 3, 5-8, 10). Inset 2 represents an updated Paleogene-Miocene evolutionary sketch with age of deformation along major faults (modified after Schmid et al., 2008). 1: Cerna strike-slip fault; 2: Timok strike-slip fault; 3: Getic Depression strike-slip system; 4: Carpathian foredeep; 5: Subcarpathian thrust; 6: Marginal Fold thrust; 7: Tarcau thrust; 8: Audia thrust. Inset 3: Evolution of the sedimentary basins through time and the assumed type of subsidence control. 
basin developed in the west (Fig. 11, also Rabagia and Matenco, 1999). In a similar way, the Petrosani basin transtension (Fuegenschuh and Schmidt, 2005) relates to the initiation and emplacement of Audia and Tarcau nappes. Once the available space in front of the Tisza-Dacia block had been consumed, a general inversion started in the Middle Miocene (Rabagia et al., 2011) and the docking of TiszaDacia was finalized (Fig. 11).

This new tectonic model of the Southern Carpathians is likely to impact our understanding of the regional petroleum systems, because it implies an early stage of burial for the Oligocene-Lowermost Miocene source rocks, at least in the inner parts of the foothills, in areas likely to charge the Tarcau thrust-related petroleum fields. The impact of the Paleogene deformations upon source rock maturity remains to be quantified, before refining the associated play concepts and driving the exploration towards new targets.

\section{ACKNOWLEDGMENTS}

We thank the editor of this OGST issue, Prof. F. Roure, for inviting us to prepare this contribution as well as for his editorial work on the manuscript. The draft was reviewed by three journal referees, Dr. K. Leever and two anonymous reviewers. We acknowledge particularly the thorough and useful review done by Dr. K. Leever.

\section{REFERENCES}

Atanasiu I. (1958) Les faciès du flysch dans les Carpates Orientales, Annuaire du Comité Geologique 24-25, 29-99.

Bancila I. (1958) Geology of the Eastern Carpathians, Editura Stiintifica, 367 p. (in Romanian).

Berza T., Draganescu A. (1988) The Cerna-Jiu fault system (South Carpathians, Romania), a major Tertiary transcurrent lineament, Dari de seama ale sedintelor Institutului de Geologie si Geofizica 72-73, 43-57.

Berza T., Krautner H.G., Dimitrescu R. (1983) Nappe structure of the Danubian window of the central South Carpathians, Analele Institutului de Geologie si Geofizica 60, 31-34.

Belayouni H., Di Staso A., Guerrera F. et al. (2009) Stratigraphic and geochemical study of the organic-rich black shales in the Tarcau nappe of the Moldavidian Domain (Carpathian Chain, Romania), Int. J. Earth Sci. 98, 157-176.

Bombita G., Bratu E., Gheta N., Ion J. (1980) The large foraminifera from the Getic Depression and the limits of their study, Dari de seama ale sedintelor Institutului de Geologie si Geofizica $\mathbf{5 5}, 45-95$ (in Romanian).

Bucur I. (1966) Contributions à la connaissance de brèches de l'Oligocène de la vallée de Siriu (Monts de Buzau), Dari de seama ale sedintelor Institutului de Geologie si Geofizica 53, 477-483.

Bucur I., Costea I., Dragu C. (1968) Correlations in the Paleogene series between Teleajen and Buzau valleys, Dari de seama ale sedintelor Institutului de Geologie si Geofizica 55, 97-109 (in Romanian).
Contescu L. (1974) Geologic history and paleogeography of Eastern Carpathians: Example of Alpine Geosynclinal Evolution, $A A P G$ Bull. 58, 2436-2476.

Csontos L., Nagymarosy A., Horvath F., Kovac M. (1992) Tertiary evolution of the Intra-Carpathian area: a model, Tectonophysics 208, 221-241.

Fugenschuh B., Schmid S.M. (2005) Age and significance of core complex formation in a very curved orogen: Evidence from fission track studies in the South Carpathians (Romania), Tectonophyiscs 404, 33-53.

Gigliuto L., Grasu C., Loiacono F., Miclaus C. et al. (2004) Provenance changes and sedimentology of the Eocene-Oligocene "Moldovita Lithofacies" of the Tarcau Nappe (Eastern Charpatians, Romania), Geologica Carpathica 55, 4, 299-309.

Gilbert D. (2007) Exploration in Romania - from yesterday to tomorrow, Presentation at the Conference 150 years of the Romanian petroleum industry, October 26th, Bucharest.

Grigoras N. (1955) The Paleogene facieses between Putna si Buzau valleys, Anuarul Comitetului Geologic 28, 122-165 (in Romanian).

Hlauschek H. (1950) Roumanian crude oils, AAPG Bull. 34, 755-781.

Iancu V., Berza T., Seghedi A., Gheuca I., Hann H.-P. (2005) Alpine polyphase tectono-metamorphic evolution of the South Carpathians: A new overview, Tectonophysics 410, 337-365.

Jipa D. (1966) Relationship between longitudinal and transversal currents in the Paleogene of the Tarcau Valley (Eastern Carpathians), Sedimentology 7, 299-305.

Jipa D. (1980) Sedimentological features of the basal Paleogene in the Valsan Valley, in Cretaceous and Tertiary molasses in the Eastern Carpathians and Getic Depression, Guidebook fieldworks group 3.3, Sandulescu et al. (eds), Romanian Institute of Geology and Geophysics, pp. 17-31.

Jipa D. (1982) Explanatory notes to lithotectonic profile of the Getic Paleogene deposits (Southern Carpathians, Romania). Sedimentological comment to Annex 13, Veroff. Zentralinst. Phys. Erde AdW DDR, 137-146.

Jipa D. (1984) Large scale progradation structures in the Romanian Carpathians: facts and hypothesis, Anuarul Institutului de Geologie si Geofizica 64, 445-463.

Joja T. (1952) Geological structure of the marginal flysch from the region of the Suha Mica and Suha Mare valleys, Dari de seama ale sedintelor Institutului de Geologie si Geofizica 36, 137-158 (in Romanian).

Matenco L., Bertotti G. (2000) Tertiary tectonic evolution of the external East Carpathians (Romania), Tectonophysics 316, 255-486.

Melinte M., Brustur T. (2008) Oligocene-Lower Miocene events in Romania, Acta Palaeontologica Romaniae 6, 203-215.

Merten S., Matenco L., Foeken J.P.T., Stuart F.M., Andriessen P.A.M. (2010) From nappe stacking to out-of-sequence postcollisional deformtions: Cretaceous to Quaternary exhumation history of the SE Carpathians assessed by low-temperature thermochronology, Tectonics 29, TC3013, doi:10.1029/2009TC002550.

Miclaus C., Loiacono F., Puglisi D., Baciu D. (2009) EoceneOligocene sedimentation in the external areas of the Moldavide basin (Marginal Folds Nappe, Eastern Carpathians, Romania): sedimentological, paleontological and petrographic approaches, Geologica Carpathica 60, 5, 397-417.

Morariu D.C., Teodorescu D.E. (1988) Geological report on the Arges and Valsan valleys, Archiva Prospectiuni S.A. (unpublished, in Romanian).

Morley C.K. (1996) Models for relative motion of crustal blocks within the Charpathian region, based on restoration of the outer Carpathian thrust sheets, Tectonics 15, 885-904. 
Motas C. (1983) Nouvelles données sur les rapports structuraux entre les Carpathes Méridionales et la Dépression Gétique, Analele Institutului de Geologie si Geofizica 60, 141-146.

Murgeanu G. (1941) Recherces geologiques dans la Vallée de Doamnei et la Vallée de Valsan (Mountenie occidentale), Comptes Rendus de Séances de l'Institut de Géologie 26, 63-86.

Mutihac V. (1990) Geological structure of Romania, Editura Tehnica, 418 p. (in Romanian).

Nastaseanu S. (1984) Geology of the main coal basins in Romania, Analele Institutului de Geologie si Geofizica 64, 195-204.

Patrut I. (1955) Geology and tectonics of the Valenii de Munte Cosminele Bustenari region, Anuarul Comitetului Geologic 28 (in Romanian).

Pawlewicz M. (2007) Total petroleum systems of the CarpathianBalkanian basin province of Romania and Bulgaria, U.S. Geological Survey Bull. 2204-F, 17 p.

Popescu B.M. (1995) Romania's petroleum systems and their remaining potential, Petrol. Geosci. 1,337-350.

Popescu G. (1952) Zone of the Paleogene flysch between the Buzau and Varbilau valleys, Dari de seama ale sedintelor Institutului de Geologie si Geofizica 31, 113-143 (in Romanian).

Popescu G. (1958) Recherches sur la "brèche de sel" et quelques massifs de sel de la Zone paléogène-miocène de Prahova (Valachie), Comtes Rendus de Séances de l'Institut de Géologie et Géophysique 36, 85-107.

Popescu G., Bratu E., Gheta N., Popescu D. (1976) Contributions to the stratigraphy of the Paleogene formations between Olt and Olanesti rivers (Getic Depression), Dari de seama ale sedintelor Institutului de Geologie si Geofizica 62, 265-278 (in Romanian).

Puglisi D., Badescu D., Carbone S. et al. (2006) Stratigraphy, petrography and palaeogeographic significance of the Early Oligocene « menilite facies » of the Tarcau nappe (Eastern Carpathians, Romania), Acta Geologica Polonica 56, 105-120.

Rabagia T., Matenco L. (1999) Tertiary tectonic and sedimentological evolution of the South Carpathians foredeep: tectonic versus eustatic control, Mar. Petrol. Geol. 16, 719-740.

Rabagia T., Matenco L., Cloething S. (2011) The interplay between eustacy, tectonics and surface processes during a growth of a faultrelated structure as derived from sequence stratigraphy: The Ocnele Mari-Govora antiform, South Carpathians, Tectonophysics 502, 196-220.

Roban R.D. (2008) Sedimentological analysis of the Paleogene formations in the NE part of the Getic Depression: paleoenvironmental reconstructions, $P h D$ Thesis, Bucharest University, $242 \mathrm{p}$. (in Romanian)

Roban R.D., Melinte M. (2005) Paleogene litho- and biostratigraphy of the NE Getic Depression (Romania), Acta Palaeontologica Romaniae 5, 423-439.

Rosu V. (2005) Contribution of the Tertiary tectonic events to the geological structure and genesis of the hydrocarbon fields from Getic Depression, the sector between the Olt and Jiu valleys, $P h D$ Thesis, Bucharest University, 240 p. (in Romanian).
Roure F., Roca E., Sassi W. (1993) The Neogene evolution of the outer Carpathian flysch units (Poland, Ukraine and Romania): kinematics of a foreland/fold-and-thrust belt system, Sediment. Geol. 86, 177-201.

Rusu A., Popescu G., Melinte M. (1996) Oligocene-Miocene transition and main geological events in Romania, Romanian $J$. Paleontology 76 (excursion guide).

Ryer M. (1998) Sequence stratigraphy and geologic evolution of the Paleogene and Lower Miocene strata, eastern Getic Basin, Romania. PhD Thesis, Bucharest University, 230 p.

Sandulescu M. (1984) Romania's geotectonics, Editura Tehnica, 450 p. (in Romanian).

Sandulescu M. (1988) Cenozoic tectonic history of the Carpathians, in The Panonnian Basin: a study in basin evolution, Royden L.H., Horvath F. (eds), AAPG Memoir 45, 17-25.

Schmid S., Bernoulli D., Fügenschuh B., Matenco L., Schefer S., Schuster R., Tischler M., Ustaszewski K. (2008) The AlpineCarpathian-Dinaridic orogenic system: correlation and evolution of tectonic units, Swiss J. Geosci. 101, 139-183.

Small W.M. (1959) Thrust faults and ruptured folds in Romanian oil fields, AAPG Bull. 43, 455-471.

Stefanescu M. (1995) Stratigraphy and structure of the Cretaceous and Paleogene flysch deposits between Prahova and Ialomita valleys, Romanian J. Tectonics Regional Geol. 76, 1-49.

Stefanescu M., Marunteanu M. (1980) Age of the Doftana Molasse, Dari de seama ale sedintelor Institutului de Geologie si Geofizica 65, 169-182.

Stefanescu M., Popescu I., Ivan V., Melinte M. (1993) Aspect of the possibilities of lithological correlation of Oligocene-Lower Miocene deposits of the Buzau valley, Romanian J. Stratigraphy 75, 89-90.

Stefanescu M., Dicea O., Butac A., Ciulavu D. (2006) Hydrocarbon geology of the Romanian Carpathians, their foreland, and the Transylvanian basin, in The Carpathians and their foreland: geology and hydrocarbon resources, Golonka J., Picha F.J. (eds), AAPG Memoir 84, 521-567.

Sylvester Z., Lowe D. (2004) Textural trends in turbidites and slurry beds from Oligocene flysch of the East Carpatians, Romania, Sedimentology 51, 945-972.

Tarapoanca M., Tambrea D., Avram V., Popescu B.M. (2007) The geometry of the South Carpathians sole thrust and the Moesia boundary: the role of inherited structures in establishing a transcurrent contact on the concave side of the Carpathians, in Thrust Belts and Foreland Basins: From Fold Kinematics to Hydrocarbon Systems, Lacombe O., Lave J., Roure F., Verges J. (eds), Frontiers in Earth Sciences, pp. 492-508. 